\title{
Hypogonadism and Cryptorchidism
}

\author{
Wiwat Rodprasert ${ }^{1,2 *}$, Helena E. Virtanen ${ }^{1,2}$, Juho-Antti Mäkelä ${ }^{1,2}$ and Jorma Toppari ${ }^{1,2,3}$ \\ ${ }^{1}$ Research Centre for Integrative Physiology and Pharmacology, Institute of Biomedicine, University of Turku, Turku, Finland, \\ ${ }^{2}$ The Population Research Centre, University of Turku, Turku, Finland, ${ }^{3}$ Department of Pediatrics, Turku University Hospital, \\ Turku, Finland
}

OPEN ACCESS

Edited by:

Rodolfo A. Rey,

Center for Endocrinology Research Dr. César Bergadá (CEDIE), Argentina

Reviewed by:

Rod Mitchell,

University of Edinburgh,

United Kingdom

Andrew A. Dwyer

Boston College, United States

*Correspondence:

Wiwat Rodprasert

wiwat.rodprasert@utu.fi

Specialty section: This article was submitted to

Reproduction,

a section of the journal

Frontiers in Endocrinology

Received: 01 September 2019

Accepted: 11 December 2019

Published: 15 January 2020

Citation:

Rodprasert W, Virtanen HE,

Mäkelä J-A and Toppari J (2020)

Hypogonadism and Cryptorchidism.

Front. Endocrinol. 10:906

doi: 10.3389/fendo.2019.00906
Congenital cryptorchidism (undescended testis) is one of the most common congenital urogenital malformations in boys. Prevalence of cryptorchidism at birth among boys born with normal birth weight ranges from 1.8 to $8.4 \%$. Cryptorchidism is associated with a risk of low semen quality and an increased risk of testicular germ cell tumors. Testicular hormones, androgens and insulin-like peptide 3 (INSL3), have an essential role in the process of testicular descent from intra-abdominal position into the scrotum in fetal life. This explains the increased prevalence of cryptorchidism among boys with diseases or syndromes associated with congenitally decreased secretion or action of androgens, such as patients with congenital hypogonadism and partial androgen insensitivity syndrome. There is evidence to support that cryptorchidism is associated with decreased testicular hormone production later in life. It has been shown that cryptorchidism impairs long-term Sertoli cell function, but may also affect Leydig cells. Germ cell loss taking place in the cryptorchid testis is proportional to the duration of the condition, and therefore early orchiopexy to bring the testis into the scrotum is the standard treatment. However, the evidence for benefits of early orchiopexy for testicular endocrine function is controversial. The hormonal treatments using human chorionic gonadotropin ( $\mathrm{hCG}$ ) or gonadotropin-releasing hormone $(\mathrm{GnRH})$ to induce testicular descent have low success rates, and therefore they are not recommended by the current guidelines for management of cryptorchidism. However, more research is needed to assess the effects of hormonal treatments during infancy on future male reproductive health.

Keywords: undescended testis, testosterone, gonadotropins, Leydig cell, Sertoli cell

\section{INTRODUCTION}

Cryptorchidism (undescended testis, maldescendus testis) is a condition in which one or both testes fail to descend into the bottom of the scrotum (1). Instead, the testis is found at a location along the normal route of testicular descent, and it may have an intra-abdominal, inguinal, suprascrotal, or high scrotal position. Congenital cryptorchidism is one of the most common congenital malformations in boys. Its prevalence at birth among boys with birth weight more than $2,500 \mathrm{~g}$ has been reported to range from 1.8 to $8.4 \%$ (2). The prevalence at the age of 3 months and 1 year is $0.9-1.6$ and $1.0-1.5 \%$, respectively, which are lower than the prevalence at birth due to spontaneous testicular descent $(2,3)$. Prevalence at birth for boys with preterm birth and/or low birth weight varies from 1.1 to $45.3 \%$ (3).

Cryptorchidism is associated with a future risk of poor semen quality and increased incidence of testicular germ cell tumors (TGCT) $(4,5)$. The risk of TGCT is increased 2-5-fold when compared 
to the general population $(5,6)$. Notably, early treatment of cryptorchidism does not significantly reduce the risk of TGCT later in life $(7,8)$. These findings support the testicular dysgenesis syndrome (TDS) hypothesis, which suggests that cryptorchidism and TGCT have a common origin in fetal life $(9,10)$.

There is evidence to support that cryptorchidism is associated with decreased testicular hormone concentrations. On the other hand, congenital hypogonadism may have cryptorchidism as one of the manifestations. The classical definition of hypogonadism is testicular dysfunction associated with androgen deficiency (11). However, Rey et al. have proposed a more comprehensive description, which would include age-dependent testicular dysfunction, including impaired Leydig cell and/or Sertoli cell function and/or a disorder of spermatogenesis (11).

In this article, we will review the literature from human studies focusing on the associations between congenital cryptorchidism and reproductive hormone levels. We conducted a Pubmed search between March and October 2019 with no publication date limit. We used the following keywords for literature search: "cryptorchidism," "undescended testis," "hypogonadism," "hormone," "testicular descent," “androgen," "testosterone," "FSH," "follicle-stimulating hormone," "LH," "luteinizing hormone," “inhibin," "INSL3," "insulin-like peptide 3," "Sertoli cell," "Leydig cell," "puberty," “cord blood," "mini-puberty," "prepuberty," "adult," "fertility," “anti-Müllerian hormone, "reproductive," "gonadotropin," "syndromic cryptorchidism," "acquired cryptorchidism," "hypogonadotropic hypogonadism," "congenital hypogonadotropic hypogonadism," "hCG," "human chorionic gonadotropin," "LHRH," “GnRH," “post-natal, "hormonal therapy," "orchiopexy," "fertility," "infertility, "testicular dysgenesis syndrome," "Klinefelter syndrome," and "Kallmann syndrome." We limited the literature search to articles in English. Full texts of the relevant articles were obtained. Reference lists of these articles were also checked to identify additional studies. We classified the studies according to different periods of life-birth, mini-puberty, prepuberty, puberty, and adulthood. The connection of cryptorchidism with semen quality and/or fertility have been extensively reviewed elsewhere $(12,13)$, therefore these topics are not the focus of this article.

\section{TESTICULAR LOCATION}

Normal position of the testis is inside the scrotum, where the center of the testis is at or below the border between the upper and lower half of the scrotum (14). Retractile testis is a testis that can be pulled to the bottom of the scrotum and does not return up immediately after release. A High scrotal position means that a testis is at the upper part of the scrotum. Some testes at the high scrotal position can be drawn to the middle or the bottom of the scrotum, but immediately after release they return to the original position, which distinguishes them from retractile testes. Suprascrotal position is the area above the scrotum. The testis may also be close to the external inguinal ring. The testis at the inguinal position stays inside the inguinal canal, which is sometimes difficult to palpate, but

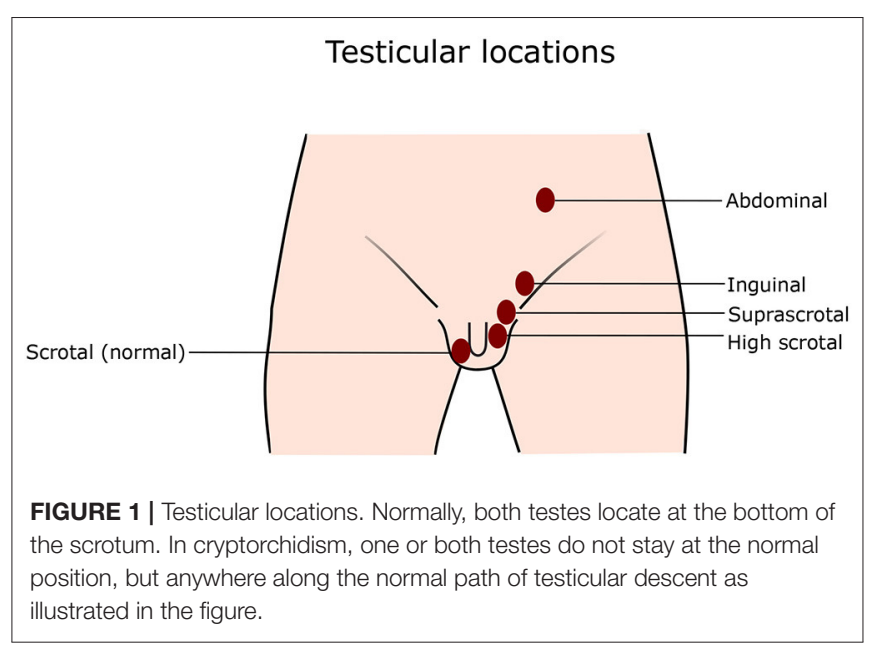

can be visible with ultrasonography (14). Retractile testes and testes with scrotal position are considered normal. In rare cases, the testis is located outside the normal path of the testicular descent, and is called ectopic testis. In this case, the testis can be located at, for instance, perineal, femoral, or pubopenile area, or at a crossed scrotal position. When a testis is non-palpable, it probably has an inguinal, abdominal, or ectopic location, or it has vanished (14-16). See Figure 1 for the illustration of different testicular positions.

\section{PHYSIOLOGY OF TESTICULAR HORMONE PRODUCTION}

Fetal Leydig cells produce testosterone and insulin-like peptide 3 (INSL3). According to the literature they start to secrete androgens during gestational weeks (GW) 8-10, and the highest levels of these hormones are measured around GW 16 (17-20). Dihydrotestosterone (DHT) converted from testosterone by 5alpha reductase mostly in peripheral tissues, is crucial for the differentiation of male external genitalia and prostate during GW 8-12 (17-19). Androgen secretion in fetal Leydig cells is stimulated by human chorionic gonadotropin (hCG) from the placenta during the first trimester of pregnancy and later by luteinizing hormone $(\mathrm{LH})$ from the anterior pituitary gland of the developing fetus $(19,21)$. Placental hCG also regulates the secretion of INSL3, which is a peptide hormone of insulin-related gene family (22), and essential for the transabdominal phase of testicular descent (23). INSL3 is also involved in testicular descent in mice by acting on the gubernaculum by binding to relaxin-family peptide receptor 2 (RXFP2), which is also known as leucine-rich repeat-containing $G$ protein-coupled receptor 8 (LGR8) and G protein-coupled receptor affecting testis descent (GREAT) $(24,25)$.

Plasma hCG levels drop rapidly after GW 10 and continue to decline slowly after GW 20 (21). Pituitary gonadotropes start producing FSH and $\mathrm{LH}$ around GW 9, and the hormones are detected in the fetal blood by GW 12-14 (26). The gonadotropin levels reach their peaks at midgestation and subsequently 
decrease toward the time of delivery $(21,26)$. LH shares the same receptor (LHCGR) with hCG on the Leydig cells (21). LH takes over the role of hCG to control androgen and INSL3 secretion from Leydig cells at around GW 15-20 (21, 27). FSH has an essential role in promoting Sertoli cell proliferation and stimulation of anti-Müllerian hormone (AMH) and inhibin B production from Sertoli cells (28-30). The gonadotropin levels decline steadily toward the time of delivery (31). For a comprehensive overview of reproductive hormone production during pregnancy, see Scott et al. (32).

Gonadotropin and testosterone levels start to rise again about 1 week after birth and peak at the age of 1-3 months, a period also known as mini-puberty $(30,31)$. During this period, there is an increased proliferation of Leydig cells (33), Sertoli cells (34), and germ cells (35). The post-natal surge of gonadotropins is also associated with accelerated penile growth (36), testicular descent (37), increased prostatic activity (38), and male sex-typed behavior at 14 months (39). Mini-puberty is also associated with an increase in testicular volume and inhibin B levels, reflecting the growing number of Sertoli cells (40-42). Furthermore, it has also been shown that the transformation of gonocytes into type A-dark (Ad) spermatogonia, i.e., stem cells for spermatogenesis, is completed during this period $(43,44)$, and therefore this developmental period is essential for adult fertility (44). Interestingly, the testosterone surge stimulated by increased gonadotropin levels during mini-puberty has also been suggested to have a role in this process as one study showed that cryptorchid boys who received hCG treatment before orchiopexy ended up having a higher number of Ad spermatogonia than boys who underwent the operation without receiving hCG (44). However, the role of androgen in this process is still unclear, and animal studies do not provide a strong support for it (45). Notably, however, the timing of germ cell development is different between mouse and man, and the results from mouse work cannot be directly extrapolated to human (46). After 69 months of age, LH and testosterone levels decrease rapidly to very low or undetectable levels, while the decline in FSH level is also substantial but remains detectable. Plasma levels for all these hormones remain low for the rest of the childhood and until the time of puberty, which is characterized by reactivation of the hypothalamic-pituitary-testicular (HPT) axis, and its sustained function continuing throughout adulthood $(47,48)$.

Mini-puberty is also associated with elevated levels of inhibin B, INSL3, and AMH $(49,50)$. The inhibin B level at 3 months of age is even higher than in adulthood. After 15 months of age, the inhibin B level decreases, however it is still detectable throughout childhood $(30,47,48,51,52)$. AMH level is still high after the age of 6 months, reflecting the functional immaturity of Sertoli cells (53). Interestingly, its function in postnatal males is still unclear. Both inhibin B and AMH [also known as Müllerian inhibiting substance (MIS)] are produced by Sertoli cells. AMH is a glycoprotein homodimer, which is a member of the transforming growth factor- $\beta$ (TGF- $\beta$ ) superfamily, along with inhibins, activins, bone morphogenetic proteins (BMPs), and growth differentiation factors (GDFs) $(54,55)$. Sertoli cells start secreting AMH from approximately GW 8-9, which causes regression of Müllerian duct-derived structures, i.e., fallopian tubes, uterus and upper vagina $(20,56,57)$. AMH secretion continues until the start of puberty, demarcating functional maturation of Sertoli cells $(56,57)$. Inhibin B is a heterodimeric glycoprotein hormone in the TGF- $\beta$ superfamily. It is composed of one inhibin $\alpha$ subunit and one inhibin $\beta_{B}$ subunit. Inhibin B suppresses FSH secretion from the anterior pituitary gland (51). Interestingly, in childhood inhibin B is secreted solely by Sertoli cells. However, in the adult testis, mature Sertoli cells produce only $\alpha$-subunit and $\beta_{\mathrm{B}}$-subunit is produced by germ cells during early spermatogenesis $(51,58)$.

$\mathrm{AMH}$ is a testis-specific marker because an extragonadal source of AMH production is not found (29). It is detected at all ages in males (59). FSH is a moderate inducer of AMH production, whereas testosterone is a potent inhibitor of its synthesis (29). AMH level is high in the fetus, remains rather stable until birth, and is elevated during mini-puberty $(60,61)$ due to FSH surge. Although testosterone level is also high at this time, lack of androgen receptor (AR) expression renders Sertoli cells unresponsive to the inhibitory effect of testosterone (62). During prepuberty, Sertoli cells continue producing high levels of $\mathrm{AMH}$, even without FSH stimulation, because there is no strong inhibitory effect on AMH production by testosterone which is nearly absent (62). Sertoli cells start to express AR in the prepubertal testis (62). When boys enter puberty, the increased testosterone production causes high intratesticular testosterone levels, which strongly inhibit AMH production and overcome the stimulatory effect of FSH (55), hence resulting in a low AMH level. This effect persists until adulthood (62). Therefore, serum AMH is a biomarker of immature Sertoli cell function during prepuberty (62). In humans, the presence of androgen receptors in Sertoli cells is necessary for the downregulation of AMH expression (63). However, the downregulation of AMH expression in mouse Sertoli cells does not require androgen action (64). Mice with a selective ablation of androgen receptor in Sertoli cells (SCARKO mice) or androgen receptor knockout (ARKO) mice with an ubiquitous ablation of androgen receptor display a strong downregulation of AMH expression during the first weeks after birth and early puberty (64). Notably, in men with congenital hypogonadotropic hypogonadism $(\mathrm{CHH}), \mathrm{AMH}$ levels remain high after puberty due to the lack of testosterone effect (65).

In adult men, the hypothalamus secretes GnRH in a pulsatile manner stimulating the pituitary gonadotrophs to release FSH and LH. FSH stimulates the secretion of inhibin B from Sertoli cells (66). Both FSH and high intratesticular testosterone promote spermatogenesis. LH acts on Leydig cells in the testicular interstitium and stimulates the secretion of INSL3 and testosterone. INSL3, unlike testosterone, is not prone to the acute fluctuations of the HPG axis activity (67) because it is dependent on the long-term trophic effect of LH (68), and its levels thus reflect the number of Leydig cells and their differentiation status (67).

FSH and inhibin B are recognized as markers of Sertoli cell function and spermatogenesis $(66,69,70)$. The correlation between FSH and inhibin B levels varies according to age, suggesting that the canonical negative feedback regulation does not apply at every stage of development. The relationship 
between serum FSH and inhibin B levels during infancy is not clear, but the negative association is likely established already at this age $(40,51,71)$. However, during early puberty, a positive association between FSH and inhibin B levels is found. In contrast, a negative association is observed during late puberty (72), and it continues into adulthood (69). A negative correlation is also observed in men with a childhood history of cryptorchidism (73).

\section{PHYSIOLOGY OF TESTICULAR DESCENT}

Testicular descent in male fetuses is a complex process. Normal function of the HPT axis and androgen secretion and action are crucial for normal testicular descent (74). The physiology of testicular descent has been extensively reviewed elsewhere $(23,46,75)$. Here, we describe this process only briefly.

Bipotential gonads are formed during weeks 4-6 of embryonic development (76). They are located on the dorsal wall of the body cavity. The primordial germ cells migrate from the extraembryonic mesoderm to the gonads via the hindgut (75). Subsequently, the differentiation of male gonads is initiated by the expression of Sex determining region of the Y-chromosome $(S R Y)$ gene, first resulting in specification of Sertoli cells and followed by Leydig cell differentiation (75). The somatic cells of the gonadal primordium start to differentiate into pre-Sertoli cells at approximately GW 7-8 (19, 20). The induction of SRY-related high-mobility group [HMG] Box 9 (SOX9) gene is the main driver of bipotential supporting cell differentiation into Sertoli cells. Subsequently, Sertoli cells proliferate, aggregate around the primitive germ cells and start tubulogenesis, i.e., the formation of testis cords (46). About 1 week after the Sertoli cells have been specified, Leydig cell differentiation is initiated in primitive interstitial cells of mesonephric origin. There is some evidence that this process might be controlled by the paracrine influences of AMH (19). During the second trimester of pregnancy, Sertoli cells proliferate rapidly, and the number of germ cells and Leydig cells also increases-adding to the volume of the testis (19).

The developing testis is anchored by two structuresthe cranial suspensory ligament attaching the upper pole of the testis to the diaphragm and the genitoinguinal ligament (gubernaculum) anchoring the testis to the future inguinal area via the epididymis $(77,78)$. Testicular descent from the abdomen to the scrotum is a complex process that is divided into two phases-transabdominal phase and inguinoscrotal phase $(23,46)$.

The transabdominal phase occurs approximately during GW 10-15. Animal studies have shown that INSL3 from the testis has a role in inducing shortening of the proximal end of the gubernaculum (gubernacular cord) and enlargement of the distal end (bulb). These effects allow the gubernaculum to hold the testis at the inguinal area while the fetus is growing (79-82). Androgens are also probably needed in this phase since the rodents exposed to antiandrogen (flutamide) before or during the outgrowth phase of the gubernaculum display disrupted inguinoscrotal descent (83). AMH may also have a role in testicular descent by causing shortening of the gubernacular cord (84). The inguinal canal is formed around the gubernaculum from early fetal life, and enlargement of gubernaculum causes dilatation of the inguinal canal, facilitating later testicular descent $(77,85,86)$. At the end of this phase, the testis is located near the deep inguinal ring. In rodents, cranial suspensory ligament (CSL) starts to regress due to androgen effect (80), but the role of CSL in testicular descent in humans is less clear $(23,75)$.

Most of the patients with cryptorchidism have disruption in the inguinoscrotal phase $(46,87,88)$. The inguinoscrotal phase starts around GW 23-25 (75). Processus vaginalis, which is a diverticulum of the peritoneal membrane, covers the testis, epididymis, and gubernaculum. These structures move through the inguinal canal as one unit (85). Subsequently, the gubernaculum starts to shrink, leaving behind only a remnant called the scrotal ligament (86). Androgens have an essential role in this phase, and therefore subjects with androgen insensitivity syndrome often have disruption in this process (89, 90). Testosterone is important during the inguinoscrotal phase, which is in contrast to the early gestation when DHT, instead of testosterone, is critical for differentiation of male external genitalia $(91,92)$. In addition, an animal study has suggested that INSL3 and its receptor (RXFP2/LGR8) also have a role in the inguinoscrotal phase (93). By the end of this phase, i.e., around birth, the testis should be located in the scrotum $(2,46)$.

It is quite common that boys with cryptorchidism at birth undergo spontaneous testicular descent before the age of 6 months, or even before 3 months of age, i.e., during minipuberty $(14,37,94-96)$. A Finnish-Danish birth cohort study demonstrated a prevalence of cryptorchidism at birth of $2.4 \%$ in Finland and $9.0 \%$ in Denmark and the prevalence at 3 months was 1.0 and $1.9 \%$ and in Finland and Denmark, respectively (14). Spontaneous descent is, however, rare after 6 months of age $(14,94,96)$. Interestingly, insulin-like growth factor 1 (IGF1) has been implicated a role in postnatal testicular descent (33). We have previously shown that postnatal distance between testis and pubic bone positively correlates with testosterone/LH ratio, inhibin B/FSH ratio, and IGF-1 level at the age of 3 months (37). Testosterone/LH ratio and IGF-1 level significantly predicted the testis-pubic bone distance at the age of 3 months, but not at 18 months of age. In contrast, inhibin $\mathrm{B} / \mathrm{FSH}$ ratio significantly predicted the distance at the age of 18 months, but not at 3 months. The results from this study suggest a role for Sertoli cell and Leydig cell function, and IGF-1 in post-natal testicular descent (37).

\section{CLASSIFICATION OF CRYPTORCHIDISM}

The majority of cryptorchid cases are detected at birth. This condition is called congenital cryptorchidism. However, some boys born with scrotal testes may later experience testicular ascent to a higher position, so-called acquired cryptorchidism (ascensus testis, ascending testis) (97). In contrast, recurrent cryptorchidism is a condition where the testis was undescended at birth but underwent spontaneous descent, subsequently followed by ascent back to a higher position (97). 


\section{Acquired Cryptorchidism}

A study in Denmark has shown that the prevalence of acquired cryptorchidism before 3 months of age is lower than after 3 months ( $0.2 \%$ at 3 months, $0.6 \%$ at 18 and 36 months) (97). This result is in agreement with a study in the UK, which showed that the prevalence of cryptorchidism was $5.9 \%$ at birth, $2.4 \%$ at 3 months, and $6.7 \%$ at 12 months (98). These findings support a role for mini-pubertal hormone surge in testicular descent. Even in normal boys, testes often descend after birth until 3 months and then ascend a little (37).

Acquired cryptorchidism complicates the interpretation of study results on congenital cryptorchidism in childhood or men in general for several reasons. First, in some studies no examination data are available at birth, especially if adult men are studied, therefore making distinction between this condition and congenital cryptorchidism more difficult. Moreover, acquired cryptorchidism has to be distinguished from retractile testis, which might be challenging. Second, patients may not be aware of this condition, and therefore the onset of acquired cryptorchidism is uncertain in most cases resulting in delay of treatment. Lastly, natural history and clinical consequences of acquired cryptorchidism are still unclear. However, evidence suggests that this condition has similar long-term adverse effects on testis as congenital cryptorchidism, as will be discussed below $(99,100)$.

\section{ETIOLOGIES OF CRYPTORCHIDISM}

Testicular descent is a complex process involving genetic, hormonal, anatomical, and environmental factors. Diseases and conditions affecting any of the associated factors can cause cryptorchidism. Several genetic disorders and syndromes are connected with cryptorchidism, so-called syndromic cryptorchidism. These conditions are characterized by decreased levels or actions of hormones involved in testicular descent, or associated with anatomical malformations $(23,101)$. Table 1 shows a list of conditions related to cryptorchidism. However, it is generally appreciated that cryptorchidism usually occurs as an isolated condition, and unassociated with any other congenital anomaly or syndrome, sometimes referred to as isolated or non-syndromic cryptorchidism $(1,120)$. Notably, the specific underlying causes in majority of cryptorchid cases cannot be identified (124). Below we discuss known conditions in which cryptorchidism is a common clinical manifestation, and different factors that are associated with cryptorchidism.

\section{Sex Chromosome Disorders}

Boys with abnormal sex chromosome number, e.g., 45,X/46,XY mosaicism, can have a wide range of external genitalia phenotypes from normal female, ambiguous (which can be asymmetric) to normal male phenotypes (17). The gonads may vary from streak gonads and dysgenetic testes to normal testes. The gonads are typically located along the normal route of testicular descent and while streak gonads tend to be at the intraabdominal position, well-formed testes are preferentially located at the inguinoscrotal region (17).
Men with Klinefelter syndrome have supernumerary $\mathrm{X}$ chromosome, which is the cause of testicular failure (125). The majority of men with Klinefelter syndrome have poor Leydig cell function during mid-to-late puberty, and congenital cryptorchidism is rather common with a reported prevalence of $27-37 \%(102,103)$. While the underlying mechanism is not known, androgen insufficiency during fetal development has been proposed. Notably, micropenis is a frequent finding in Klinefelter boys, and a small study has shown that amniotic total testosterone levels is in the female range in some boys with Klinefelter syndrome (125).

\section{Cryptorchidism in 46,XY Individuals}

Since androgens have a crucial role in the inguinoscrotal phase of testicular descent, many diseases/syndromes related to male hypogonadism or decreased androgen action can manifest as cryptorchidism (2).

\section{Disorders of Gonadal Development}

Patients with partial gonadal dysgenesis have variable internal and external genitalia phenotypes. The gonads vary from streak gonads to dysgenetic testes, or they may regress $(17,126)$. Patients with ovotesticular DSD (disorder of sex development; 46,XX, $46, \mathrm{XX} / 46, \mathrm{XY}$, or $46, \mathrm{XY}$ ) have variable manifestations of gonads (testis, ovary, or ovotestis) and internal/external genitalia, and decreased gonadal function. The testis or ovotestis can be found at any location along the route of testicular descent (17).

\section{Decreased Androgen Biosynthesis Due to Testicular Enzyme Deficiency}

Deficiencies in any of the enzymes involved in testicular synthesis of testosterone or DHT result in decreased androgen production and action, which can manifest itself since fetal life. These enzyme deficiencies are typically inherited in an autosomal recessive manner (127). A list of enzymatic defects and gene mutations are shown in Table 1.

\section{Hypogonadotropic Hypogonadism}

Boys with congenital hypogonadotropic hypogonadism frequently present with cryptorchidism and/or micropenis. Gene mutations involved in isolated hypogonadotropic hypogonadism are listed in Table 1. Mutations in the coding regions of FGFR1, GNRHR, PROK2, PROKR2, TAC3, and TACR3 genes can cause isolated hypogonadotropic hypogonadism, however, these mutations are not commonly found in patients with isolated cryptorchidism (128). A French study involving 46 boys with $\mathrm{CHH}$ reported that cryptorchidism was detected in 32 boys (69.6\%) - eight boys with unilateral and 24 boys with bilateral cryptorchidism (110). A study of 98 Brazilian men with Kallmann syndrome reported that cryptorchidism was observed in $54 \%$ of all patients, $65 \%(11 / 17)$ of patients with $K A L-1$ gene mutation (two boys with unilateral and nine boys with bilateral cryptorchidism) and $23 \%$ of patients with isolated hypogonadotropic hypogonadism (129). Importantly, placental hCG, not LH, controls androgen production during the first half of pregnancy when the transabdominal phase of testicular descent takes place (during GW10-15) and differentiation of 
TABLE 1 | Conditions associated with cryptorchidism.

\section{Diseases or syndromes associated with decreased androgen levels}

\section{Disorders of sex development (DSD)*}

\subsection{Sex chromosome DSD}

- 47,XXY (Klinefelter syndrome and variants)

- 45,X/46,XY (mixed gonadal dysgenesis)

- 46,XX/46,XY (chimerism)

\section{$1.246, X Y$ DSD}

1.2.1 Disorders of testicular development

- Complete or partial gonadal dysgenesis

Mutations in

ARX, ATRX, CBX2, DAX1 (NROB1), DHH, DHX37, DMRT1, EMX2, ESR2, FGFR2, GATA4, HHAT, MAP3K1, NR5A1, SF1, SOX9, SRY, TSPYL1, WNT4, WT1(WAGR syndrome, Denys-Drash syndrome, Frasier syndrome), ZFPM2, and ZNRF3 genes

\subsubsection{Disorders in androgen synthesis or action}

- Androgen biosynthetic defect

Abnormal LH (LHB)

Steroidogenic acute regulatory protein (StAR deficiency) (STAR)

7-Dehydro-cholesterol desmolase deficiency (Smith-Lemli-Opitz syndrome)

Cholesterol desmolase deficiency (CYP11A1)

$3 \beta$-hydroxysteroid dehydrogenase type 2 deficiency (HSD3B2)

17,20-lyase deficiency or combined 17

hydroxylase/17,20-lyase deficiency (CYP17A1)

P450-oxidoreductase deficiency (POR)

17 $\beta$-Hydroxysteroid-dehydrogenase type 3 (HSD17B3)

5-alpha reductase type 2 enzyme deficiency (SRD5A2)

Cytochrome b5 deficiency (CYB5A)

Backdoor steroidogenetic enzyme deficiency (AKR1C2, AKR1C4)

- Defect in androgen action

Partial androgen insensitivity $(A R)$

Infantile onset $\mathrm{X}$-linked spinal muscular atrophy

- LH receptor defects

Inactivating mutation of LH receptor gene (LHCGR) (Leydig cell hypoplasia, aplasia)

1.3 46,XX DSD*

- Ovotesticular DSD

- Testicular DSD (e.g. SRY+, dup SOX9, RSP01)

46,XX male

2. Congenital hypogonadotropic hypogonadism in $46, X Y^{\star *}$ :

- Isolated hypogonadotropic hypogonadism with anosmia (Kallmann syndrome)

KAL1, FGFR1/FGF8, PROK2/PROKR2, KAL1, NELF, HS6ST1, WDR11, and SEMA3A

gene mutations

CHD7 gene mutation (CHARGE syndrome)

- Normosmic isolated hypogonadotropic hypogonadism

Mutations in KISS1, GPR54, LEP, LEPR, TAC3/TACR3, and GNRH1/GNRHR genes

(Also reported mutations in FGFR1/FGF8, PROKR2, CHD7, and WDR11 genes)

- Multiple pituitary hormone deficiencies

Mutations in PROP1 genes, HESX1 gene (Septooptic dysplasia)

3. Congenital hypergonadotropic hypogonadism

- Down syndrome

- Noonan syndrome

4. Syndromes associated with both primary and secondary hypogonadism

- Prader-Willi syndrome

- Bardet-Biedl syndrome

Conditions associated with decreased INSL3 or AMH levels or actions

INSL3 or RXFP2 mutations

Persistent Müllerian duct syndrome: $\mathrm{AMH}$ and $\mathrm{AMH}$ receptor (AMH, $A M H R 2)$

\section{Other conditions related with cryptorchidism}

- Aarskog-Scott

- Acrocallosal

- Acrodysostosis

\section{7-37\%}

(102, 103)

$(106,107)$
38-69.6\%

50-70\%

$6.5 \%$

$65.7-80 \%$

80-90\%

$11-13 \%$
(108-110)

(111) 
TABLE 1 | Continued

\section{Conditions}

- Adams-Oliver

- Amyoplasia congenital disruptive sequence

- Aniridia-Wilms tumor association

- Apert

- Autosomal recessive chondroplasia punctate

- Beckwith-Wiedemann

- Cardio-facio-cutaneous

- Catel-Manzke

- Chondroectodermal dysplasia

- Cockayne

- Coffin-Siris

- Congenital microgastria-Limb reduction complex

- Delange

- Deletion 3p, 4p, 5p, 9p, 11q, 13q, 18q, 22q11.2

- Diastrophic dysplasia

- Distal arthrogryposis

- Distichasis-lymphoedema

- Dubowitz

- Duplication 3q, 9p, 10q, 15q

- Escobar

- Ectrodactylia-ectodermal dysplasia clefting

- Fanconi anemia

- Femoral hypoplasia-unusual facies

- Fetal hydantoin

- FG

- Fraser

- Freeman-Sheldon

- Frontometaphyseal dysplasia

- Fryns

- Gorlin

- Greig cephalopolysyndactyly

- Hallermann-Streiff

- Jarcho-Levin

- Johanson-Blizzard

- Langer-Giedion

- Larsen

- Lenz-Majewski hyperostosis

- Lenz Microphthalmia

- Marden-Walker

- Marshall

- McKusick-Kaufmann

- Meckel-Gruber

- Meier-Gorlin

- Miller

- Miller-Diker

- Myotonic dystrophy

- Mowat-Wilson

- Multiple lentigines

- Neu-Laxova

- Opitz G/BBB

- Oto-palato-digital (type II)

- Pallister-Hall syndrome

- Pena-Shokeir phenotype

- Peters'-plus

- Pfeiffer

- Poplietal pterygium

- Prune-Belly syndrome

- Posterior urethral valve

- Roberts-SC phocomelia

- Robinow

- Rothmund-Thomsom

- Rubinstein-Taybi 
TABLE 1 | Continued

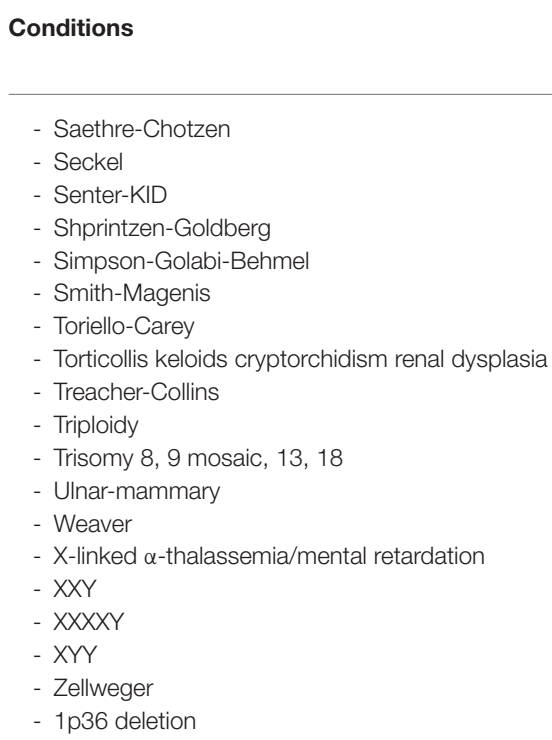

The prevalence of cryptorchidism in each syndrome that has been reported in the literature is shown.

*Modified from the consensus statement on management of intersex disorders $(121,122)$.

${ }^{* *}$ For a list of genes implicated in congenital hypogonadotropic hypogonadism, see (123).

CHD7, Chromodomain helicase DNA binding protein; DAX1, Dosage-sensitive sex reversal congenital adrenal hypoplasia critical region on the X chromosome type 1; FGFR1, Fibroblast growth factor receptor type 1; GnRH1, gonadotropin releasing hormone; GnRH-R, GnRH receptor; GPR54, G-protein coupled receptor 54 (kisspeptide receptor); HS6ST1, Heparan sulfate 6-Osulfotransferase1; LEP, leptin; LEPR, leptin receptor; NELF, Nasal embryonic LHRH factor gene; NROB1, nuclear receptor subfamily 0, group B, member 1; PROK2, prokinecitin-2; PROKR2, Prokinectin receptor 2; SEMA3A 7, Semaphorin-3A; TAC3, gene encoding neurokinin B, TACR3, gene encoding neurokinin receptor; WDR11, WD repeat-containing protein (17).

male external genitalia occurs $(18,85,130-132)$. This might explain why cryptorchidism is not found in all patients with hypogonadotropic hypogonadism (2), and these patients do not have ambiguous genitalia, as patients with testicular androgen synthesis defects. However, hypogonadotropic hypogonadism might be associated with testicular ascent during infancy (133). Patients with Prader-Willi syndrome have both central and primary hypogonadism, and almost all of them have unilateral or bilateral cryptorchidism at birth (134).

\section{Decreased Androgen Action}

In addition to male hypogonadism, patients with partial androgen insensitivity syndrome caused by androgen receptor gene mutation may also present with cryptorchidism $(89,90)$.

\section{Genetic Defects in Genes Related to Hormones Controlling Testicular Descent}

Patients with persistent Müllerian duct syndrome have normal male external genitalia, but have Müllerian structures (uterus, fallopian tubes, and upper vagina) (135). This is because Müllerian ducts do not regress during fetal life due to absence of $\mathrm{AMH}$ function. The syndrome is caused by an inactivating mutation in a gene encoding $\mathrm{AMH}$ or its receptor (AMHRII gene). Patients may present with bilateral cryptorchidism, unilateral cryptorchidism with contralateral hernia, or transverse testicular ectopia (135). The reason for cryptorchidism may be anatomical hindrance of testicular descent. However, there is also evidence that $\mathrm{AMH}$ may act on gubernaculum by shortening it (84). Interestingly, mice with Amh defects have normal testicular descent (136). Unlike AMH, INSL3 has a clear role in testicular descent in mice (79-81). However, INSL3 and LGR8 gene mutations are rare in cryptorchid patients (137139).

\section{Genetic Syndromes and Other Genetic Defects}

Cryptorchidism may also occur as part of a genetic syndrome with unclear underlying mechanisms, including Down syndrome and Noonan syndrome. Boys with Down syndrome have an increased risk of both congenital and acquired cryptorchidism (112). Hypergonadotropic hypogonadism has been reported in some boys with Down syndrome and Noonan syndrome, which might explain the increased risk of cryptorchidism in the affected boys $(112,140)$. In addition, another proposed mechanism of acquired cryptorchidism in Down syndrome is an impaired migration of the spermatic cord along the path of the gubernaculum and impaired cord elongation (112).

\section{Anatomical Defect of the Abdominal Wall, or Decreased Abdominal Pressure}

Cryptorchidism is also found in other syndromes and defects not associated with androgen deficiency, including Prune belly syndrome, posterior urethral valve, and abdominal wall defects (121). This suggests that a mechanical defect is causing cryptorchidism (101). 


\section{Maternal Condition, Environmental Exposure, and Other Factors}

Although several genetic disorders and syndromes have been associated with cryptorchidism, the specific causes in the majority of cryptorchid cases cannot be identified (124). Individual factors that have some association with cryptorchidism are low birth weight, small for gestational age, preterm birth, family history of cryptorchidism, maternal heavy cigarette smoking, caffeine consumption during pregnancy, endocrine-disrupting chemical exposure or medication use during pregnancy, maternal gestational diabetes, low parity, and paternal smoking during pregnancy $(2,121,141,142)$. These factors are postulated to disrupt fetal testicular development and cause testicular dysgenesis syndrome (TDS). According to the TDS hypothesis, some male reproductive disorders/manifestations, including cryptorchidism, hypospadias, lowered semen quality, testicular germ cell tumors, decreased serum testosterone level, and short anogenital distance, may share the same origin in fetal life $(9,10$, 124, 143).

An endocrine-disrupting chemical (EDC) is an exogenous substance or mixture that modifies function(s) of the endocrine system and consequently causes adverse health effects in an intact organism, or its progeny, or (sub) populations (144). Some EDCs show anti-androgenic or estrogenic effect, or affect androgen or INSL3 levels or action during fetal development in animal studies (145). Animal studies have demonstrated that exposure to anti-androgen or estrogen during a critical period of male reproductive organ development during embryonic days 13.517.5 in rats (equivalent to GW $7-15$ in humans) is related to the occurrence of cryptorchidism $(9,18,146,147)$. In humans, boys with a history of in utero exposure to diethylstilbestrol, a synthetic non-steroidal estrogen, have been shown to have a twofold increased risk of cryptorchidism (148). Association between EDCs, such as dioxins, polybrominated flame retardants and pesticides, and cryptorchidism, has been reviewed in (149).

\section{HISTOLOGICAL CHANGES IN THE TESTIS OF PATIENTS WITH CRYPTORCHIDISM}

The histological changes in the cryptorchid testis include abnormalities in a variety of testicular cells. Number of germ cells per tubule were normal during the first year of life but subsequently decreases significantly, especially during 1-3 years of age $(42,150-154)$. Sertoli cell and germ cell numbers are lower in boys who have undergone orchiopexy at the age of 3 years than in those who were operated at the age of 9 months (42). During the first year of life, the number of Ad spermatogonia declined. The gonocytes disappeared from the cryptorchid testis by the age of 12 months instead of normal 6 months (152-154). This suggests an impaired transformation of gonocytes into Ad spermatogonia (152-154). A decreased number of Leydig cells was detected after the first few months after birth in cryptorchid boys $(152,153)$. In addition, interstitial or peritubular fibrosis appeared with a concomitant decrease in the number of germ cells, which worsened with increasing age in cryptorchid testes $(155,156)$. The descended testes of the boys with unilateral cryptorchidism also show histological abnormalities. These include a reduced number of Ad spermatogonia and a delayed development of primary spermatocytes (154).

\section{REPRODUCTIVE HORMONE LEVELS IN PATIENTS WITH CRYPTORCHIDISM}

There are a number of studies exploring the HPT axis hormone levels in patients with cryptorchidism. Table 2 summarizes the subjects and the main findings of these studies.

\section{AT BIRTH}

To our knowledge, two studies have investigated the cord blood levels of INSL3 in newborn boys with congenital cryptorchidism $(50,157)$. Bay et al. reported that levels of INSL3 in cord blood of Finnish, but not Danish, cryptorchid boys were significantly lower than in control boys. However, the Danish data may suffer some limitations due to a small number of subjects (50). Low INSL3 levels in cord blood of cryptorchid boys was also reported in a French study (157). LH, testosterone, hCG, $\mathrm{AMH}$, inhibin $\mathrm{B}$, and sex hormone-binding globulin (SHBG) concentrations of the cryptorchid and non-cryptorchid boys were similar (157). The low INSL3 level at birth could be a cause or a consequence of cryptorchidism-it might suggest that the cause of cryptorchidism is low secretion of INSL3 or indicate that mild Leydig cell dysfunction can be identified already at the early life of the cryptorchid boys. Sertoli cell function in cryptorchid testes seems to be normal at birth.

\section{MINI-PUBERTY}

A number of studies have investigated HPT axis hormone levels in cryptorchid boys. However, there are some differences in the findings among the studies as described below.

\section{Sertoli Cell Function}

Impaired Sertoli cell function in cryptorchid boys as compared with non-cryptorchid boys has been observed since the minipubertal period in one study $(49)$, but not in the others $(163,164)$. A birth cohort study conducted in Finland and Denmark found higher FSH and lower inhibin B levels during mini-puberty in Finnish cryptorchid boys than in healthy controls. In Denmark, cryptorchid boys had higher FSH than non-cryptorchid boys but inhibin B levels were similar (49). These results suggested an impaired Sertoli cell function among cryptorchid boys (49). A strength of this study is that it is a follow-up of a prospective birth cohort with a harmonized research protocol. However, the blood was collected at the age of 3 months in both countries, which might not attain the peak of the mini-pubertal hormone surge, as it may occur already somewhat earlier (176). In contrast to the results of the Finnish and Danish birth cohort study, a case-control study involving 1-to-6-month-old boys in the Netherlands did not show significant differences in serum FSH, inhibin B, or AMH levels between the cryptorchid and control groups (164). Similarly, a case-control study in the USA showed 
TABLE 2 | Summary of studies on reproductive hormone levels in boys with cryptorchidism and men with a history of cryptorchidism in childhood*.

\begin{tabular}{|c|c|c|c|c|}
\hline First authors & $\begin{array}{l}\text { Study design } \\
\text { Country of investigation } \\
\text { Study subjects }(n)\end{array}$ & $\begin{array}{l}\text { Age at hormone } \\
\text { measurements, } \\
\text { hormonal tests }\end{array}$ & Comparisons & Hormone results \\
\hline
\end{tabular}

\section{At birth}

Bay et al. (50)

Fénichel et al. (157)

\section{Mini-puberty}

Gendrel et al. (158)

Baker et al. (159)

De Muinck

Keizer-Schrama et al.

(160)

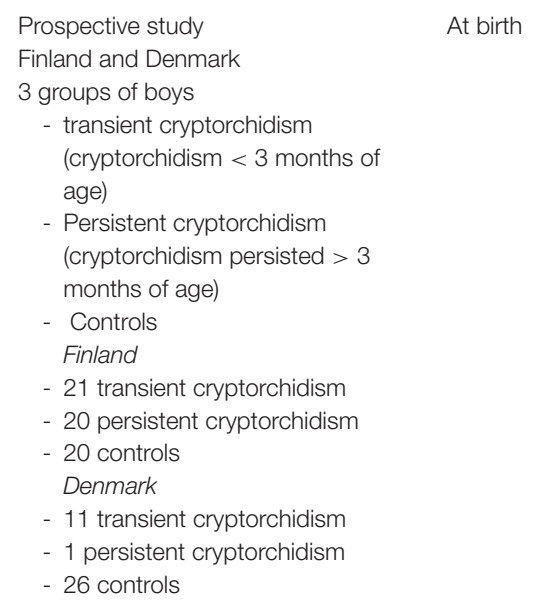

Prospective study

Finland and Denmark

3 groups of boys

- transient cryptorchidism

(cryptorchidism $<3$ months of

age)

- Persistent cryptorchidism

(cryptorchidism persisted $>3$

months of age)

- Controls

Finland

- 21 transient cryptorchidism

- 20 persistent cryptorchidism

- 20 controls

Denmark

- 11 transient cryptorchidism

- 1 persistent cryptorchidism

- 26 controls

At birth

Prospective case-control study

France

26 boys with transient cryptorchidism

26 boys with persistent

cryptorchidism

128 controls

Longitudinal study
France

57 term cryptorchid boys

- 35 unilateral cryptorchidism

- 22 bilateral cryptorchidism

Cryptorchid boys classified into

two groups:

-Spontaneous testicular descent

-Persistent cryptorchidism >

6 months

Case-control study

United Kingdom

Cases: 21 boys born preterm (mean

gestational age of 30 weeks)

- 11 boys with unilateral

cryptorchidism

- 10 boys with

bilateral cryptorchidism

Controls: 21 boys matched for

gestational age, birthweight,

duration of ventilation assistance

and duration of phototherapy

Longitudinal study

The Netherlands

Three groups of boys, aged $<1$ y:

Cryptorchidism persisted $>1$ y $(n=$

29) (untreated)

Spontaneous descent within 1 y $(n=$ 19)

Controls $(n=160)$

At birth months

-2 days

5 days

67 days)

levels

peak
Cryptorchid vs. non-cryptorchid boys

Cryptorchid vs. non-cryptorchid boys

Every month from the age of 1 to 4

Mean age of blood sampling

weekly until

hospital discharge

(mean age of

Only plasma T

were measured.

At 3, 6, 12

months: Basal and

LHRH-stimulated

serum $\mathrm{LH}$ and

FSH Basal T

At 12 months:

Basal and

post-hCG

stimulation: T,

$\mathrm{DHT}$, and

T precursors
Cryptorchidism with spontaneous testicular descent vs. persistent cryptorchidism

Cryptorchid vs. non-cryptorchid boys

Persistent vs. transient cryptorchidism vs. controls
Cord blood INSL3 level in Finnish boys with cryptorchidism was significantly lower than in controls. (non-significant difference in Danish boys)
Plasma FSH was not different between 2 groups.

Plasma LH and T levels were significantly lower in persistently cryptorchid boys.
At 2 days and after 6 weeks: Cryptorchid boys had significantly lower plasma T levels than controls.
Basal, peak LHRH-stimulated $\mathrm{LH}$ and FSH levels were not different between three groups, except basal serum $\mathrm{LH}$ in group 2 was higher than that of group 3.

Basal and peak LHRH-stimulated serum $\mathrm{LH}$ and $\mathrm{FSH}$ levels had similar changes over time.

Basal and post-hCG stimulated serum levels of DHT and T precursors were not different between three groups. 
TABLE 2 | Continued

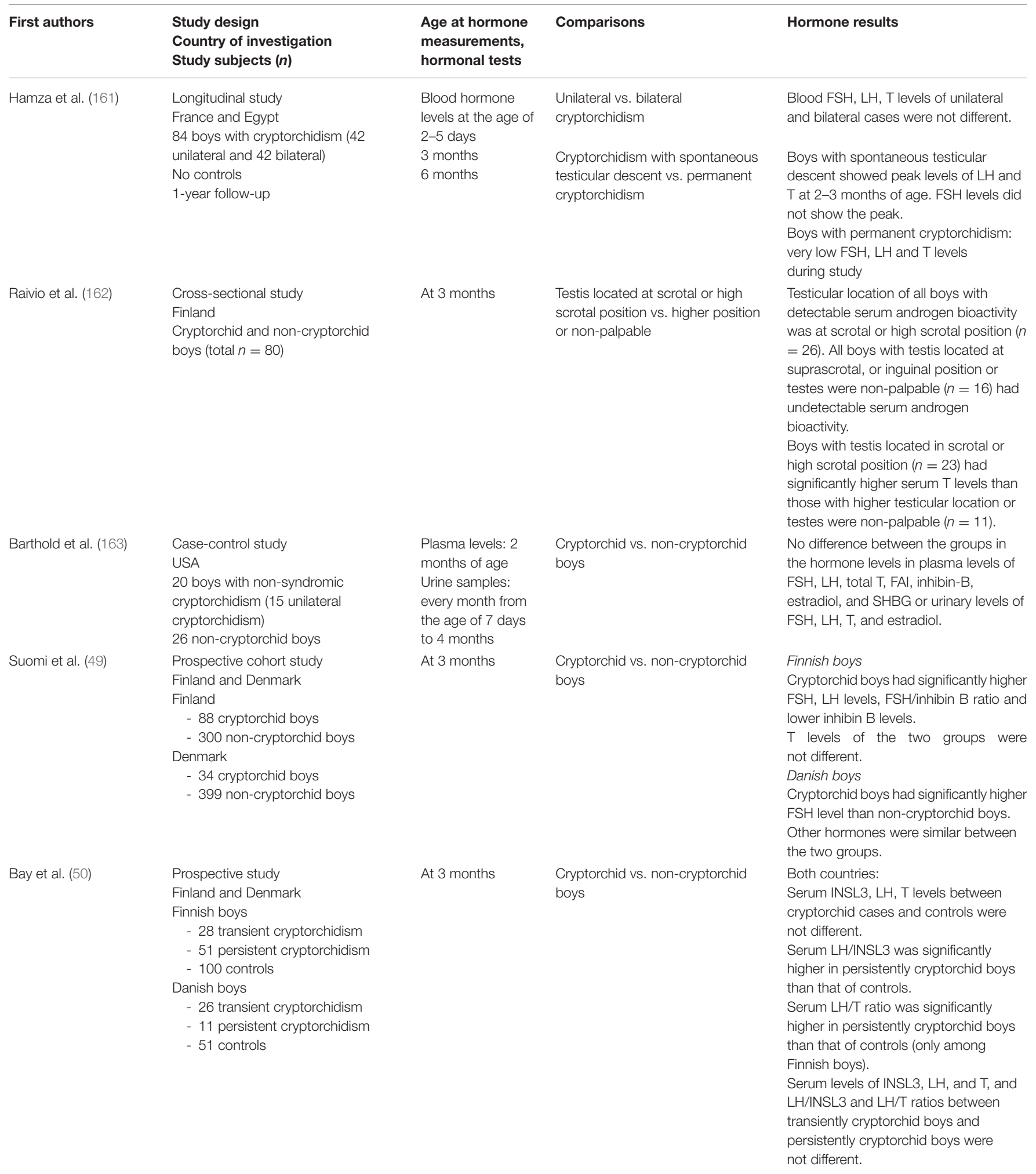


TABLE 2 | Continued

\begin{tabular}{ll}
\hline First authors & $\begin{array}{l}\text { Study design } \\
\text { Country of investigation } \\
\text { Study subjects }(\boldsymbol{n})\end{array}$ \\
\hline Pierik et al. (164) & $\begin{array}{l}\text { Case-control study } \\
\text { The Netherlands } \\
43 \text { boys with cryptorchidism } \\
113 \text { controls }\end{array}$ \\
Prepuberty & $\begin{array}{l}\text { Cross-sectional study } \\
\text { Gendrel et al. (165) }\end{array}$ \\
& $\begin{array}{l}\text { France } \\
\text { - Unilateral cryptorchidism }(n=64) \\
\text { or }\end{array}$ \\
& - Bilateral cryptorchidism $(n=90)$ \\
& 46 controls
\end{tabular}

De Muinck Keizer-Schrama et al. (160) Longui et al. (166)

Christiansen et al. (167)

Cross-sectional study

Denmark

62 boys with untreated

cryptorchidism

(45 unilateral and 17 bilateral

cryptorchidism)

156 healthy, prepubertal boys

Iwatsuki et al. (168)

Komarowska et al. (169)

Hypospadias ( $n=49$ )

Cryptorchidism and hypospadias ( $n=$ 10)

Hydrocele $(n=7)$

Cross-sectional study

Poland

\section{Age at hormone Comparisons \\ measurements, \\ hormonal tests}

At 1-6 months

\section{1 month-15 y}

mean age: 2.2 y

Median age $7.7 \mathrm{y}$, ranged from 4.1 to $13.6 \mathrm{y}$

12.5 to $13.5 \mathrm{y}$

Boys with unilateral cryptorchidism (n

$=105$ )

Boys with inguinal hernia (controls) ( $n$ $=58$ )
At age:

$<12.5 \mathrm{y}$

$>13.5 \mathrm{y}$

and by Tanner

stages

Compare four groups of boys

$$
\text { Age 1-4 y }
$$

Cryptorchid vs. controls

LHRH test

Cryptorchid boys vs. control levels

hCG stimulation test

Boys with a history of cryptorchidism vs. controls

Cryptorchid vs. non-cryptorchid boys

Unilateral vs. bilateral cryptorchidism

Hormone levels of cryptorchid boys after 3-week hCG injection ( $n$ $=18$ )

Hormone results

Serum FSH, inhibin B, and AMH levels: not different between the 2 groups. Cryptorchid cases had significantly lower T and NSBT levels.

Peak LH levels in boys with history of cryptorchidism were significantly lower than controls (from infancy to early pubertal stage).

FSH levels of boys with history of cryptorchidism and controls: no difference

Basal plasma T levels: no difference between cases and controls Peaked T levels: blunted in boys with a history of cryptorchidism from the age of 1 year until mid-puberty

Basal LH and T concentrations were not different between the 2 groups Boys with a history of cryptorchidism had significantly lower basal inhibin and higher FSH levels than controls. After hCG plus human menopausal gonadotropin (hMG) treatment, the inhibin-to-FSH ratio was significantly lower in boys with a history of cryptorchidism.

Basal inhibin B, T, FSH, and LH levels between cryptorchid cases and healthy controls: no difference

Basal levels of inhibin B, T, FSH, and LH between boys with unilateral and bilateral cryptorchidism: no difference After hCG treatment in cryptorchid boys, $T$ increased into the adult range and $\mathrm{FSH}$ and $\mathrm{LH}$ were suppressed. FSH levels in boys with both cryptorchidism and hypospadias was significantly higher than those of the other groups at ages 12.5-13.5 and $>13.5 \mathrm{y}$, and during Tanner stages II and III.

$\mathrm{LH}$ and $\mathrm{T}$ levels were not different among the groups.

Boys with unilateral cryptorchidism vs. non-cryptorchid boys
Serum AMH, INSL3, and inhibin B of the two groups were not different. 
TABLE 2 | Continued

\begin{tabular}{ll}
\hline First authors & $\begin{array}{l}\text { Study design } \\
\text { Country of investigation } \\
\text { Study subjects }(\boldsymbol{n})\end{array}$ \\
\hline Hamdi et al. (170) & Cross-sectional study \\
& France \\
& Cases: boys operated for \\
& cryptorchidism ( $n=27)$ \\
& controls ( $n=27)$ \\
& Age range: 14-32 months \\
& \\
Grinspon et al. (171) & Retrospective, cross-sectional study \\
& Argentina \\
& Cryptorchid group \\
& Untreated bilateral cryptorchidism $(n$ \\
& $=186)$ \\
& Untreated unilateral cryptorchidism $(n$ \\
& $=124)$ \\
& Apparently normal boys (controls) $(n$ \\
& $=179)$
\end{tabular}

\section{Puberty}

Gendrel et al. (165)

Dickerman et al. (172)
Described in the pre-pubertal section

Longitudinal study

Israel

106 boys with cryptorchidism

- unilateral $(n=77)$

- bilateral $(n=29)$

Follow-up at least two times per year from the age of 5-14 y (Mean age $11.6 \mathrm{y})$

\section{Age at hormone \\ measurements, \\ hormonal tests}

Mean age

Cases: boys

operated for

cryptorchidism:

26.6 months

Control group:

24.4 months

Median age 3 y

(range 0.03-13.6

y)

Cryptorchid vs. non-cryptorchid

boys

Unilateral vs. bilateral

cryptorchidism vs. controls in each age group

- 1-5.9 months

- 6 months- 1.9 y

$-2-8.9 y$

$-\geq 9 \mathrm{y}$

Plasma FSH and LH levels before and after $\mathrm{LHRH}$ test

Plasma T level

before and after

hCG stimulation

test

The hormone

levels were

compared with

normal range.
LHRH test: Unilateral vs. bilateral cryptorchidism vs. range for normal boys for chronological age at various pubertal stages according to data from previous studies

hCG stimulation test: unilateral vs. bilateral cryptorchidism vs. range for normal boys for chronological age at various pubertal stages

\section{Adulthood}

Lee and Coughlin (4)
Cohort study

USA

Men with a history of bilateral

cryptorchidism ( $n=8$ )

Men with a history of unilateral

cryptorchidism ( $n=109)$

Control men $(n=53)$
Adult age

Unilateral vs. bilateral cryptorchidism vs. controls
Hormone results

Serum inhibin B, AMH and testosterone levels of the boys operated for cryptorchidism were significantly lower than that of non-cryptorchid boys. ( $T$ levels were detectable in 10 cases and 10 controls.)

Median AMH standard deviation score (for age of normal boys) in the cryptorchid group was below 0 .

Serum AMH level of boys with bilateral cryptorchidism was significantly lower than that of the unilateral cryptorchidism and control groups between the age of 6 months to $1.9 \mathrm{y}$ and between 2 to $8.9 \mathrm{y}$.

Serum FSH and LH levels were not different between the three groups at any ages.

- Basal FSH level in boys with unilateral cryptorchidism during prepuberty and bilateral cryptorchidism at mid-puberty and full puberty: higher than normal reference range.

- Basal LH in boys with bilateral cryptorchidism: higher than normal reference range.

- Post LHRH test, FSH level in cryptorchid boys: higher than normal reference range.

- Post LHRH test, LH level: higher than normal range in boys with unilateral cryptorchidism at prepuberty and at mid-puberty.

- At the start of puberty: Unilateral cryptorchidid boys: basal and posthCG stimulated T levels were higher than normal reference range.

- At mid-puberty: basal $T$ level in bilateral cryptorchidism group, aged 14-16 y, was lower than normal reference range.

- At the end of puberty: basal T level in unilateral group was lower than normal reference range. T level after hCG stimulation was lower than normal reference range in cryptorchid boys.

Men with a history of bilateral cryptorchidism had significantly lower inhibin B, significantly higher FSH and LH levels than men with a history of unilateral cryptorchidism and control men. 
TABLE 2 | Continued

\begin{tabular}{|c|c|c|c|c|}
\hline First authors & $\begin{array}{l}\text { Study design } \\
\text { Country of investigation } \\
\text { Study subjects }(n)\end{array}$ & $\begin{array}{l}\text { Age at hormone } \\
\text { measurements, } \\
\text { hormonal tests }\end{array}$ & Comparisons & Hormone results \\
\hline Brazao et al. (173) & $\begin{array}{l}\text { Retrospective case-control study } \\
\text { The Netherlands } \\
\text { Group1: subfertile men with } \\
\text { orchiopexy in childhood ( } n=64 \text {, } \\
\text { including } 32 \text { unilateral and } 32 \text { bilateral } \\
\text { cryptorchidism) } \\
\text { Group 2: non-cryptorchid subfertile } \\
\text { men ( } n=128) \\
\text { Group 3: fertile men }(n=32)\end{array}$ & $\begin{array}{l}\text { Median age: } \\
\text { Group 1: } 31 \text { y } \\
\text { Group 2: } 33 \text { y } \\
\text { Group 3: } 32 \text { y }\end{array}$ & $\begin{array}{l}\text { Subfertile men with orchiopexy in } \\
\text { childhood vs. non-cryptorchid } \\
\text { subfertile men vs. fertile men }\end{array}$ & $\begin{array}{l}\text { Inhibin B levels of men in group } 1 \text { were } \\
\text { significantly lower than those of men in } \\
\text { group } 2 \text { and } 3 \\
\text { FSH and LH levels in group } 1 \text { were } \\
\text { significantly higher than those of group } \\
2 \text { and } 3 \\
\text { FAl: no difference }\end{array}$ \\
\hline Andersson et al. (174) & $\begin{array}{l}\text { Cross-sectional } \\
\text { Denmark } \\
357 \text { infertile men, including } 72 \text { men } \\
\text { with a history of cryptorchidism } \\
\text { (median age: } 33 \text { y) } \\
318 \text { fertile men, including } 42 \text { men } \\
\text { with a history of cryptorchidism } \\
\text { (median age: } 30 \text { y) } \\
\text { Self-reported data }\end{array}$ & Adult age & Fertile vs. infertile men & $\begin{array}{l}\text { Among both fertile and infertile men, } \\
\text { history of cryptorchidism was } \\
\text { associated with decreased serum } \\
\text { inhibin B levels. } \\
\text { Among infertile men, history of } \\
\text { cryptorchidism was associated with } \\
\text { higher LH level, lower T/LH ratio and } \\
\text { lower estradiol level. }\end{array}$ \\
\hline Rohayem et al. (175) & $\begin{array}{l}\text { Retrospective case-control study } \\
\text { Germany } \\
\text { Men with a history of cryptorchidism } \\
\text { with or without treatment ( } 222 \\
\text { unilateral and } 135 \text { bilateral } \\
\text { cryptorchidism) } \\
\text { Men with no history of cryptorchidism } \\
\text { and had normozoospermia and } \\
\text { normal testicular size at adult age ( } n \\
=709) \\
\text { Age: } 16-58 \text { y }\end{array}$ & $\begin{array}{l}\text { Mean age: } \\
\text { Previous unilateral } \\
\text { cryptorchidism: } 34 \\
\text { y } \\
\text { Previous bilateral } \\
\text { cryptorchidism: } 33 \\
\text { y } \\
\text { Control men: } 35 \text { y }\end{array}$ & $\begin{array}{l}\text { Men with history of unilateral vs. } \\
\text { bilateral cryptorchidism }\end{array}$ & $\begin{array}{l}\text { Mean FSH and LH levels: significantly } \\
\text { higher in men with a history of } \\
\text { cryptorchidism } \\
\text { Mean total and free T levels: } \\
\text { significantly lower in men with a history } \\
\text { of cryptorchidism } \\
\text { Estradiol: no difference } \\
\text { Men with a history of bilateral } \\
\text { cryptorchidism: significantly higher } \\
\text { mean FSH and LH levels } \\
\text { Mean total and free T, estradiol levels: } \\
\text { no difference }\end{array}$ \\
\hline
\end{tabular}

*Some studies included subjects at different periods of life. The studies are described in the section, in which the main results are reported.

$D H T$, dihydrotestosterone; FAl, free androgen index; T, testosterone; y, year.

that the levels of serum and urinary testosterone, estradiol, $\mathrm{LH}$ and FSH, and plasma levels of inhibin B and SHBG of the cryptorchid and non-cryptorchid boys were not different (163).

\section{Leydig Cell Function}

Mild Leydig cell dysfunction in cryptorchid boys during minipuberty has been demonstrated. Low testosterone levels or decreased post-natal testosterone peak has been reported in a number of studies, especially when patients with severe, persistent cryptorchidism were compared with milder cases (49, 158, 159, 161, 164, 177). A study in Finland and Denmark found higher LH level, LH/testosterone, and LH/free testosterone, but similar testosterone levels in cryptorchid boys as compared to controls, suggesting mild Leydig cell dysfunction with compensatory response by the pituitary gland (49). Boys with persistently severe cryptorchidism (one or both testes found at the suprascrotal or inguinal area or non-palpable at the age of 3 months) had significantly lower testosterone levels than boys with mild cryptorchidism (high scrotal position) with non-significantly higher LH levels (49). The LH/INSL3 ratio and $\mathrm{LH} /$ testosterone ratio were higher in persistently cryptorchid boys than in controls, however, INSL3 levels of the two groups were similar (50). When compared to boys with at least one testis located in a suprascrotal or a higher position at 3 months of age, boys with scrotal or high scrotal testes had higher androgen bioactivity (162), which is a measure of androgen action at the cellular level by using sensitive in vitro receptor bioassays (178). Leydig cell failure becomes evident in persistently severe cryptorchidism and the study subjects are likely analyzed with primary defects in Leydig cells, rather than Leydig cell dysfunction secondary to prolonged malposition of the testis $(49,50,162)$.

In contrast, some studies have shown low testosterone and low LH levels in cryptorchid boys suggesting pituitary gland dysfunction (158, 161, 164). A study conducted in Egypt and France reported that the peak plasma $\mathrm{LH}$ and testosterone levels were low in persistently cryptorchid boys as compared to boys with spontaneously descended testis (161). A Dutch study demonstrated that cryptorchid boys had a lower testosterone and non-SHBG-bound testosterone (NSBT) than those of controls, whereas serum levels of SHBG, LH, FSH, AMH, and inhibin B were not different between the two groups (164). However, the authors reported that the proportion of boys with testosterone levels under the limit of detection was higher among cryptorchid 
boys aged 100 days or above than among controls. This finding might explain the lower testosterone and NSBT levels among cryptorchid boys as compared to the controls in this study. A study of preterm boys in the UK also found reduced peak testosterone levels in 1-2-month-old cryptorchid boys as compared to healthy controls (159). While there is clear evidence supporting decreased androgen levels in the minipubertal cryptorchid testis, yet two studies did not find any differences in the HPT axis hormone levels during mini-puberty between cryptorchid and non-cryptorchid boys $(160,163)$.

In conclusion, during mini-puberty Leydig cell function seems to be preserved in mildly and transiently cryptorchid boys but impaired in more severe and persistent cases. On the other hand, studies on Sertoli cell function have given inconsistent results. Only one study found a decreased Sertoli cell function as shown by lower inhibin-B and higher FSH levels.

The differences in the results of the reproductive hormone levels during mini-puberty may vary depending on the age at diagnosis, age at blood sampling (whether they were at the peak of HPT axis hormone secretion or not), severity of cryptorchidism, possible inclusion of retractile testis, or spontaneously resolved cases, syndromes associated with hypogonadotropic hypogonadism, size of the studies and sensitivity of the hormone assays. There are only a few studies that have reported the position of the testis, thus also indicating the severity of cryptorchidism or the underlying conditions associated with cryptorchidism, such as hypogonadism $(49,50$, $162,163)$.

\section{PREPUBERTAL PERIOD}

The HPT axis becomes inactive $\sim 6$ months after birth in boys before its reactivation at the onset of puberty. During this prepubertal period, the levels of $\mathrm{FSH}, \mathrm{LH}$, and testosterone measured by routine laboratory methods are very low or undetectable in normal boys (56). Therefore, the measurement of basal levels of these hormones during this period is generally not useful for evaluation of the HPT axis function. Endocrine stimulation tests, including hCG stimulation test and GnRH test, are required for the assessment of presence of a testis and the function of prepubertal Leydig cells therein (179). In contrast, serum inhibin B and AMH levels are still detectable during this period in normal boys, which reflects the function of Sertoli cells $(57,180)$.

Pituitary gonadotroph function can be assessed by $\mathrm{GnRH}$ [also called luteinizing hormone-releasing hormone (LHRH)] stimulation test, and Leydig cell function can be evaluated by hCG stimulation test $(179,181)$. hCG is a glycoprotein hormone primarily produced by the placenta (179). It has a similar structure to $\mathrm{LH}$ and shares the same receptor as LH (LHCG receptor; LHCGR) on the Leydig cells. Compared to LH, hCG has 24 additional amino acids at the carboxy-terminal end, which increases its biological effect, plus a sialic acid terminal on a carbohydrate chain makes its half-life longer. As a result, hCG can sustainably stimulate steroid hormone production and can be used to test Leydig cell steroidogenic capacity
(179). GnRH upregulates GnRH receptors on gonadotrophs and the expression level of gonadotropin subunit genes in the pituitary (181). A single intravenous injection of $\mathrm{GnRH}$ at a dose of $2.5 \mu \mathrm{g} / \mathrm{kg}$ stimulates $\mathrm{LH}$, and to a lesser extent, FSH secretion from the anterior pituitary gland. Subcutaneous $\mathrm{GnRH}$ administration is less frequently used. The peak LH response to $\mathrm{GnRH}$ administration is used for the assessment of pubertal status (182). The peak LH and FSH levels are higher in peripubertal boys than those of the prepubertal boys (183). In prepubertal boys, the LH and FSH levels increase two- to four-fold after $\mathrm{GnRH}$ administration as compared to the basal level, and the peak LH/FSH ratio is about 0.7. Postpubertally, LH level increases 6- to 10-fold, and FSH increases four- to six-fold after $\mathrm{GnRH}$ administration, and the mean peak LH/FSH ratio is about 3.5 (184). A blunted FSH and LH response suggests hypogonadotropic hypogonadism-either pituitary or hypothalamic dysfunction (181, 183). A sensitive gonadotropin assay, such as an immunofluorometric assay, is needed for reliable and sensitive testing (185). During prepuberty the GnRH test is not very informative because gonadotropin levels do not yet increase at this age, and therefore, differential diagnosis between $\mathrm{CHH}$ and a constitutional delay of puberty is difficult (186).

In summary, studies on Leydig cell function during the prepubertal period rely on the hCG-stimulated testosterone levels, while Sertoli cell function can be assessed by measuring basal inhibin B and AMH levels.

\section{Sertoli Cell Function}

The basal levels of FSH and inhibin B of cryptorchid and non-cryptorchid boys have been found similar in a handful of studies $(160,165,167)$. One study also reported no difference of these basal hormone levels between boys with unilateral and bilateral cryptorchidism (167). FSH levels after the GnRH test were similar between boys with transient cryptorchidism (spontaneously descended testis within 1 year of life), persistent cryptorchidism, and the controls, suggesting normal secretion of FSH in cryptorchid boys (160).

However, other studies have found lower inhibin B and $\mathrm{AMH}$ levels at the age of 2 years (170), lower AMH level between the age of 6 months to 8.9 years (171), and lower inhibin B and higher FSH levels at the mean age of 2 years in the cryptorchid boys as compared to controls, suggesting impaired Sertoli cell function (166). A study conducted in Japan demonstrated that FSH levels were higher in boys who had both cryptorchidism and hypospadias as compared to boys with cryptorchidism only, boys with hypospadias only and controls at the age of more than 12.5 years (168). The boys who had only cryptorchidism or only hypospadias had comparable FSH level as the controls. This might suggest that combined cryptorchidism and hypospadias are associated with a more severe testicular dysfunction, which supports the TDS hypothesis (168).

\section{Leydig Cell Function}

Basal LH and testosterone levels, if still detectable, were found to be similar in cryptorchid and non-cryptorchid boys in some studies (160,166-168). Other studies found that basal 
testosterone and LH levels were lower in cryptorchid boys, suggesting pituitary dysfunction in cryptorchid boys $(170,177)$. However, LH levels after the GnRH test between boys with transient cryptorchidism, persistent cryptorchidism, and controls were similar, which did not support the concept of pituitary failure in cryptorchid boys (160). It is worth noting that the gonadotropin responses in the $\mathrm{GnRH}$ test start to increase around the time of onset of puberty which might bias the results. Three studies compared testosterone levels following the hCG stimulation test between cryptorchid cases and controls. One study reported that the levels of the two groups were not different (160), but other two studies found blunted testosterone response after hCG stimulation $(165,177)$.

In conclusion, the available literature on Sertoli cell function in cryptorchid testis during prepuberty is inconsistent. While most studies suggest that Sertoli cell function is normal during prepuberty, some studies argue against it. Leydig cell function is generally regarded normal during this period.

\section{PUBERTY}

The puberty in males starts when the testicular volume exceeds $3 \mathrm{~mL}$, as assessed by an orchidometer (187-189). This co-occurs with increased levels of serum gonadotropins, testosterone, and inhibin B (58, 72, 190-195). Only two old studies have explored the reproductive hormone levels in cryptorchid boys during puberty $(165,172)$.

A longitudinal study published in 1979 followed a group of boys with a history of unilateral $(n=77)$ and bilateral $(n=$ 29) cryptorchidism from the mean age of 11.6 years (range 514 years) to the time of full pubertal maturation (172). The hormonal data of these boys were compared to the normal range of hormones for chronological age at each pubertal stage. The study found that the basal and GnRH-stimulated FSH and LH levels in boys with a history of cryptorchidism were higher than normal during puberty, and the basal and hCGstimulated testosterone levels were lower than normal after midpuberty (172).

A 1977 study reported the results of a GnRH test and hCG stimulation test in 154 boys with cryptorchidism (64 unilateral and 90 bilateral), aged 1 month to 15 years (165). Plasma LH levels before and after the GnRH test were normal (165). However, the rise of plasma testosterone after hCG stimulation was reduced until mid-puberty. There was a positive correlation between testosterone level after the hCG stimulation test and LH level before and after the GnRH test (165).

\section{DURING ADULTHOOD}

It has been clearly shown that men with a history of cryptorchidism have an increased risk of infertility and TGCTs (6, 12), however, studies showing a long-term impact on hormonal levels in adulthood are more limited, and the results are not consistent.

\section{Sertoli Cell Function}

Studies have reported higher levels of serum FSH or lower inhibin B or both in men with a history of cryptorchidism when compared to non-cryptorchid men, which suggests impaired
Sertoli cell function (4, 173-175). Men with a history of bilateral cryptorchidism have lower sperm concentration and inhibin B levels, but higher FSH and LH levels than those in the unilaterally cryptorchid or control group (4).

\section{Leydig Cell Function}

Some studies have found significantly higher serum LH and lower testosterone/LH ratio in men with a history of cryptorchidism as compared to controls, whereas testosterone levels were normal, indicating mild Leydig cell dysfunction with a compensatory pituitary response $(173,174)$. Yet, other studies have reported low testosterone and high LH concentrations in men with a history of cryptorchidism, which suggested a more severe Leydig cell dysfunction (4, 73, 175). Impaired Leydig cell function seems to be more related with bilateral cryptorchidism as shown in one study which found lower testosterone levels in men with a history of bilateral cryptorchidism than in men with a history of unilateral cryptorchidism (173).

A possibility that some men with acquired cryptorchidism have been included in the studies on adult reproductive health cannot be ruled out, and particularly data from retrospective studies might be prone to recall bias. Men with a history of unilateral acquired cryptorchidism were found to have significantly smaller testes (both the previously undescended testis and the contralateral descended testis), lower sperm concentration and lower percentage of sperm motility than controls (196). FSH, LH, testosterone, and inhibin B levels were similar between men with previously unilateral acquired cryptorchidism and controls. Interestingly, sperm concentration, percentage of progressive sperm motility, serum FSH, LH, testosterone, and inhibin $\mathrm{B}$ levels between men with a history of unilateral acquired cryptorchidism or unilateral congenital cryptorchidism do not differ (196). These parameters were also not different between men with bilateral acquired and bilateral congenital cryptorchidism (196).

In summary, current evidence suggests that cryptorchid boys have rather normal Sertoli cell and Leydig cell function at birth. The function of Sertoli cells starts to decline from the mini-pubertal period until adulthood as shown by decreased serum inhibin B and elevated FSH levels. Leydig cell function is preserved in boys with mild and transient cryptorchidism, but the function can be impaired in boys with severe and persistent cryptorchidism. Leydig cell function starts to decline from mid-puberty onwards. Some studies showed compensated Leydig cell function in adulthood as shown by normal serum testosterone but elevated serum LH level, which is worse in bilateral cryptorchidism than in unilateral cryptorchidism. However, there is likely variation in Leydig cell function given the fact that some studies demonstrated more severe functional failure of Leydig cells.

\section{PUBERTAL DEVELOPMENT OF BOYS WITH CRYPTORCHIDISM AND TESTICULAR SIZE IN ADULTHOOD}

Age at pubertal onset of boys with a history of cryptorchidism is not different from that of the healthy boys $(189,197)$, which 
is also supported by another study showing that testosterone level was not low at the start of puberty in cryptorchid boys (172). A Danish study found that self-reported signs of pubertal development of cryptorchid boys from the age of 11.5 years to the end of puberty or until the age of 18 years were not different from controls (198). However, a Finnish study found that age at the first self-reported conscious semen ejaculation was higher in boys with a history of cryptorchidism than in controls (197).

Seminiferous tubule compartment, composed of Sertoli cells and germ cells, accounts for $80-90 \%$ of testicular volume of adult human testis (199). Thus, testicular size of adult men reflects the reproductive capacity. In boys with a history of unilateral or bilateral cryptorchidism, the prepubertal growth of previously undescended testes does not differ from controls, however, at the end of puberty these testes are found smaller (189). The descended testis of boys with a history of unilateral cryptorchidism or monorchid testis, on the other hand, were bigger than that of the controls before puberty, but are found similar in volume at the end of puberty (189). In individuals with unilateral cryptorchidism, the previously undescended testis was smaller than the contralateral, normal testis from puberty to adulthood $(172,200)$. Interestingly, the testicular volumes of the operated testes and spontaneously descended testes were not different among boys with a history of unilateral cryptorchidism (189), which suggests that the testes were damaged in both conditions. However, a randomized treatment study showed that early orchiopexy is beneficial for prepubertal testicular growth (201). When testicular growth is monitored in boys with a history of congenital unilateral cryptorchidism, testicular volume of the boys who underwent orchiopexy at the age of 9 months increased significantly from the ages of 6 months to 4 years, whereas no testicular growth was observed in boys who underwent orchiopexy at 3 years (201). The spontaneously descended testes of the boys with congenital unilateral cryptorchidism were smaller than the contralateral, scrotal testes at all ages during a follow-up from birth to 5 years of age (202).

Studies in the adult men showed that testicular volume of subfertile cryptorchid men was smaller than that of noncryptorchid subfertile men or fertile men from the general population (173). Somewhat surprisingly, the mean testicular volume of men with a history of bilateral cryptorchidism was bigger than that of formerly unilateral cryptorchid testes (200). However, both were smaller than the mean volume of normally descended testes of men with a history of unilateral cryptorchidism (200). A study in men with a couple infertility found that bi-testicular volume of the men with a history of unilateral cryptorchidism was bigger than that of the men with a history of bilateral cryptorchidism (175).

\section{POTENTIAL MECHANISMS OF CRYPTORCHIDISM-INDUCED HYPOGONADISM}

To date, the mechanisms of hypogonadism in cryptorchidism are still elusive. There is evidence suggesting that from minipuberty until adulthood serum inhibin B is lower and serum
FSH level is higher in cryptorchid boys than in normal boys. During prepuberty, AMH levels are also lower in cryptorchid boys. This suggests an abnormal function in the testis rather than a defect in the hypothalamus or pituitary gland. Studies on Leydig cell hormone levels show contradictory results. Leydig cell hormone secretion seems to be better preserved in cryptorchidism than Sertoli cell function, suggesting that Leydig cells might be more tolerant of the abnormal testicular position than Sertoli cells. However, some studies in mini-puberty and adulthood have also shown elevated LH levels accompanied with normal testosterone levels, suggesting compensated Leydig cell dysfunction. Furthermore, a few studies have shown high LH and low testosterone levels, indicating a severe Leydig cell failure.

One proposed mechanism behind the adverse effects of cryptorchidism is the higher ambient temperature in the undescended testis. Temperature in the scrotum is $33^{\circ} \mathrm{C}$, which is about $4^{\circ} \mathrm{C}$ lower than the core body temperature. Ambient scrotal temperature of around $33^{\circ} \mathrm{C}$ is seminal for the function of the testis after birth $(203,204)$. Higher temperature is considered to impinge especially on germ cells and it has been suggested that gonocytes require a lower ambient temperature for maturation (205). However, the importance of temperature on Sertoli cell and Leydig cell function is still unclear.

In men with unilateral cryptorchidism, the contralateral descended testis is also characterized by abnormal development (206) and has an increased risk of testicular cancer (207). This can be related to the underlying cause of cryptorchidism and the shared risk factors of testicular cancer in both testes. These findings also support the TDS hypothesis that was described earlier.

\section{FACTORS AFFECTING REPRODUCTIVE HORMONE LEVELS AND TESTICULAR SIZE IN PATIENTS WITH CRYPTORCHIDISM}

\section{Age at Treatment}

There is some evidence showing that early orchiopexy in cryptorchid patients is associated with higher serum inhibin B and/or lower FSH levels, suggesting better Sertoli cell function, as compared with late orchiopexy (before vs. after 2 years of age in a US study, before vs. after 5 years in a Dutch study and before vs. after 8 years in a Slovenian study) $(73,173,208)$. Early orchiopexy was also associated with higher sperm concentration (173). A large case-control study conducted in Germany reported that age at correction of cryptorchidism (including patients treated with orchiopexy, hCG, or GnRH analogs) positively correlated with serum FSH and LH and negatively with testicular volume and sperm concentration (175). There was no correlation between age at correction of cryptorchidism and serum testosterone level (175). This is consistent with another study that found no correlation between age at orchiopexy and salivary testosterone level in men with a history of bilateral cryptorchidism (209). However, a study of unilateral cases in the US found an inverse correlation between age at orchiopexy and serum total testosterone level (210). Another study did not show the 
relationship between age at orchiopexy and serum hormone levels at the adult age (211). However, the results were not presented in detail, and e.g., correlation coefficients were not reported (211).

Boys who underwent orchiopexy and testicular biopsy at the age of 9 months had higher numbers of germ cells and Sertoli cells and larger testicular volume than boys who were operated and biopsied at 3 years of age (42). The spontaneously descended testes had similar testicular size at follow-up. Testicular volume at the time of operation correlated positively with the number of germ cells and Sertoli cells in the group treated at 9 months of age and it also associated positively with the number of Sertoli cells, but not germ cells, in the group treated at 3 years of age (42). The number of germ cells at 3 years of age was very low, therefore they do not contribute much to the testicular volume (42). In another study, increased duration of undescended testis was significantly associated with increased depletion of germ cells (OR 1.02, for each month) and Leydig cells (OR 1.01, for each month) (212). A systematic review and meta-analysis in 2018 showed that boys who underwent orchiopexy before the age of 1 year had $0.06 \mathrm{~mL}$ larger testicular volume (95\% CI 0.01-0.10) and higher number of spermatogonia per tubule [mean difference 0.47 (95\% CI 0.31-0.64)] than those operated after 1 year of age (213). After orchiopexy in boys with unilateral cryptorchidism, serum inhibin B increased, and serum FSH decreased, suggesting an improved Sertoli cell function (214).

Taken together, early orchiopexy is associated with a better outcome for Sertoli cell function and higher number of germ cells. However, the benefits of this practice for Leydig cell function, as shown by testosterone and LH levels, are controversial.

\section{Unilateral or Bilateral Diseases}

The testicular hormone levels in bilateral cryptorchidism seem to be lower than those in unilateral cryptorchidism. Studies have revealed that men who were operated for bilateral cryptorchidism had higher FSH and LH levels and lower inhibin B levels than men who were operated for unilateral cryptorchidism or the controls, while testosterone levels were comparable between the groups $(4,211)$. A study conducted in Argentina found that risk factors for low AMH levels (less than third percentile) during prepuberty were bilateral cryptorchidism and the coexisting micropenis (171).

\section{Histology of Testis at Orchiopexy}

A US study investigated serum reproductive hormones and semen analysis in adult men with a history of cryptorchidism who underwent orchiopexy and testicular biopsy of both testes (91 unilateral and 19 bilateral cryptorchidism) (215). Men who had a history of unilateral cryptorchidism and 0.1 or less Ad spermatogonia per tubule had significantly higher FSH levels than unilateral cryptorchid men with more than 0.1 Ad spermatogonia per tubule. However, this finding was not significant in bilaterally cryptorchid men, possibly due to a small number of subjects with a history of bilateral cryptorchidism (215).

\section{Testicular Location Before Orchiopexy}

Testicular location of unilateral cryptorchidism before orchiopexy had no influence on paternity rate, duration of attempted conception before achieving paternity, sperm count, testosterone, or FSH levels in a study of 103 men with a history of unilateral cryptorchidism (216). A history of inguinal cryptorchidism was associated with significantly lower adult inhibin B level than that of other locations, and a history of ectopic testis was associated with higher LH level than that of other locations (216). Men with a history of intraabdominal testes had a slightly increased risk for infertility (216). Again, a limitation of this study is the small number of cryptorchid men representing each testicular location, which possibly affects the statistical power of the study. In general, the results from this study did not support the idea that testis at a higher location is associated with poorer hormonal function.

\section{EFFECTS OF CRYPTORCHIDISM ON FERTILITY}

It has been clearly demonstrated that cryptorchidism has an adverse effect on fertility in adulthood (12). Paternity rate, as defined as the proportion of men who had fathered children or had attempted for more than 12 months, was significantly lower in men with formerly bilateral cryptorchidism than that of men with formerly unilateral cryptorchidism, or controls (12). The rates of successful paternity were 65.3 vs. 89.7 vs. $93.2 \%$, respectively (12). Cryptorchidism is associated with an increased germ cell loss and resultant impaired fertility which become the worse the longer the testis stays in the undescended position (13). In normal boys, the maximum number of germ cells is found at $\sim 3$ months of age, then the number decreases significantly during the first 3 years of life in both cryptorchid testis, and to a lesser degree, normally descended testis $(35,42,217)$. Therefore, the current guidelines for the management of cryptorchidism recommend orchiopexy before the age of 12 or 18 months (16, 218, 219).

Sperm concentration and sperm motility of men with childhood treatment of bilateral cryptorchidism were lower than those of men who were treated for unilateral cryptorchidism (208). Among men with a history of bilateral orchiopexy in childhood, serum FSH level was negatively associated with sperm concentration and serum inhibin B level (208). Serum inhibin B level had a negative correlation with FSH level (208). A study conducted in Finland found that the proportion of men who had normal sperm concentration was higher in men treated in childhood (by orchiopexy \pm hCG) for unilateral cryptorchidism than that of men treated for bilateral cryptorchidism ( 90 vs. $50 \%$, respectively) (220). All of the men who were treated for bilateral cryptorchidism before the age of 4 years had normal sperm concentration according to the WHO criteria (220), showing some benefits of early treatment. 


\section{ROLE OF HORMONAL TREATMENT IN CRYPTORCHIDISM}

Induction of testicular descent in cryptorchid boys by intramuscular hCG injection or intranasal GnRH (LHRH) administration has been used. This practice is based on the concept that androgens are crucial for testicular descent in fetal life, and testosterone surge during mini-puberty has a role in the transformation of gonocytes into Ad spermatogonia, which are stem cells for future spermatogenesis (221). Notably, testosterone levels increased significantly after the administration of hCG or GnRH (222).

Although there might be some room for hormonal treatment in the management of cryptorchidism, studies on treatment of cryptorchidism with hCG or GnRH have demonstrated low success rates and a high rate of testicular re-ascent (223225). Meta-analyses of randomized, blinded studies on hCG treatments showed a success rate of $19 \%$ (224), whereas GnRH studies showed a $21 \%$ success rate. These results represent a marginal improvement when compared to the placebo (4$6 \%$ success rate) $(16,224,226)$. Notably, the reported success rates of orchiopexy have been more than $70 \%$ in most studies $(218,225)$. A more recent meta-analysis of hCG for cryptorchidism treatment in 2018 included seven randomized controlled trials, which assessed the efficacy of treatment with parenteral hCG as compared with intranasal GnRH or placebo (227). Different doses and regimens of hCG and GnRH were used. hCG induced complete testicular descent in $0-50.8 \%$ of patients with unilateral cryptorchidism and $0-22.4 \%$ of patients with bilateral cryptorchidism (227). The Nordic consensus published in 2007, European Urology guideline in 2016, and the American Urology Association guideline in 2014 do not recommend hormonal treatment for inducing testicular descent in cryptorchid patients and recommend orchiopexy as the preferred method of treatment $(16,218,219)$. This is due to low efficacy of hormonal treatments, lack of long-term data, poor quality of studies, varied treatment protocols, and different study populations $(16,218,219)$. Also, there are reports on an increased germ cell apoptosis after discontinuation of hCG treatment and possible harmful effects on germ cells (228-230). The adverse effects of hormonal treatments are common (in about $75 \%$ of the boys), although mostly mild and can decrease after discontinuation of the treatment (218). These include increases in scrotal redness and pigmentation, scrotal rugae, amount of pubic hair, penile and testicular size, and behavioral changes, including aggressiveness $(222,225)$.

In some studies, hormonal treatments, particularly GnRH, have been used before, but also after orchiopexy or orchiolysis (231). The aim has been to improve fertility potential in addition to the orchiopexy (231). This is based on the assumption that the hormonal surge during mini-puberty has a role in the transformation of gonocytes into Ad spermatogonia, which has been suggested to be important for male fertility $(221,232)$. The number of A dark spermatogonia from testicular biopsy at the time of orchiopexy was reported to predict the risk of infertility in adulthood $(221,232)$. Some studies of GnRH administration, before (in most studies) or after orchiopexy or orchiolysis, showed increased fertility indices, as assessed by the number of germ cells or spermatogonia per tubular cross-section or percentage of normal histology from testicular biopsy in childhood, or semen quality $(16,231,233,234)$. To date, there is only one study that reported a long-term effect of hormonal treatment on semen quality in adulthood (235), therefore the combined or sequential surgical and hormonal treatment cannot be recommended as routine practice at this time.

\section{HORMONAL TREATMENT IN PATIENTS WITH CONGENITAL HYPOGONADOTROPIC HYPOGONADISM DURING INFANCY}

Congenital hypogonadotropic hypogonadism $(\mathrm{CHH})$ is a condition characterized by a decreased production, secretion, or action of GnRH (123). The patients with this condition lack FSH and LH and display the resultant low testosterone level since fetal life, and therefore they can present with micropenis or cryptorchidism at birth $(108,236,237)$. Low testosterone levels during puberty and adulthood result in absent or incomplete puberty, eunuchoid body proportions, decreased virilization, reduced libido, and sexual function, infertility, or osteoporosis from long-standing hypogonadism (123).

Additionally, $\mathrm{CHH}$ patients lack gonadotropin and testicular hormone surge during mini-puberty giving the window of opportunity of early diagnosis of this condition in infancy, which can be performed by detecting low serum FSH, LH, testosterone, and inhibin $\mathrm{B}$ as compared with the reference ranges at 4-8 weeks after birth (123). Early diagnosis allows pediatricians to plan for induction of puberty at the appropriate time preventing the potential pubertal delay (108). Since the mini-pubertal hormonal surge is associated with Sertoli cell proliferation (238), the lack of mini-puberty might relate to reduced Sertoli cell proliferation and the resultant decreased fertility later in life (237). Therefore, some studies investigated the role of replacement of deficient mini-pubertal hormones by using $\mathrm{GnRH}$, or gonadotropins during infancy in patients with $\mathrm{CHH}$ to improve reproductive health, especially fertility, later in life (237). However, only some of these studies included cryptorchid boys, and testicular descent was not the primary outcome of most of these studies, making it difficult to assess the effect of this approach on testicular descent (41,133,239-243). As far as we know, only two small studies in France and Greece have investigated the effects of gonadotropin administration during infancy in boys with $\mathrm{CHH}$ associated with cryptorchidism, and aimed at induction of testicular descent, or had testicular descent as one of the primary outcome $(244,245)$. These two studies used subcutaneous injection or infusion of rhFSH and rhLH in $\mathrm{CHH}$ infants with congenital cryptorchidism for 3 months in one study and 6 months in the other $(244,245)$. The treatment increased LH, FSH, inhibin B, and T levels to the normal or supranormal range. Complete testicular descent occurred in most patients. Their testicular size was normal. However, a few 
TABLE 3 | Summary of the studies on hormonal treatment during infancy in boys with congenital hypogonadotropic hypogonadism and cryptorchidism.

\begin{tabular}{|c|c|c|c|c|c|}
\hline First authors & $\begin{array}{l}\text { Study design } \\
\text { Country of investigation } \\
\text { Study subjects }(n)\end{array}$ & Treatment & $\begin{array}{l}\text { Age at hormone } \\
\text { measurements }\end{array}$ & $\begin{array}{l}\text { Testicular location after } \\
\text { treatment }\end{array}$ & Hormone results \\
\hline & $\begin{array}{l}\text { Long-term comparison data } \\
\text { (during adolescence) } \\
\text { Three of five } \mathrm{CHH} \text { boys with a } \\
\text { history of cryptorchidism who } \\
\text { received rhFSH and testosterone } \\
\text { in infancy had available data at } \\
\text { adolescence (age, } 10.0-12.8 \mathrm{y} \text { ) vs. } \\
\text { retrospective controls ( } 8 \mathrm{CHH} \\
\text { boys, aged } 12.7-17.8 \mathrm{y} \text { ) without } \\
\text { previous gonadotropin treatment } \\
\text { (six boys had cryptorchidism.) }\end{array}$ & & $\begin{array}{l}\text { data at adolescence } \\
\text { of three } \mathrm{CHH} \text { boys } \\
\text { with a history of } \\
\text { cryptorchidism } \\
\text { treated with rhFSH } \\
\text { and testosterone } \\
\text { during infancy vs. six } \\
\text { untreated } \mathrm{CHH} \text { boys } \\
\text { with history } \\
\text { of cryptorchidism }\end{array}$ & & $\begin{array}{l}\mathrm{CHH} \text { boys treated ( } n=3 \text { ) } \\
\text { vs. not treated with rhFSH } \\
\text { and testosterone }(n=6) \\
\text { (compared during } \\
\text { adolescence) } \\
\text { Inhibin B levels of the } \mathrm{CHH} \\
\text { boys with a history of } \\
\text { cryptorchidism who } \\
\text { received }(n=3) \text { and did not } \\
\text { receive treatment }(n=6) \\
\text { during infancy were } \\
\text { not different. }\end{array}$ \\
\hline $\begin{array}{l}\text { Lambert and } \\
\text { Bougneres (245) }\end{array}$ & $\begin{array}{l}\text { Intervention study } \\
\text { USA } \\
\text { Eight CHH boys with } \\
\text { cryptorchidism (five abdominal } \\
\text { testes and three high scrotal } \\
\text { testes), aged } 0.25-11 \text { months }\end{array}$ & $\begin{array}{l}\text { Subcutaneous infusion } \\
\text { at a daily rate of rhLH } \\
50 \mathrm{IU} \text { and rhFSH } \\
75-150 \mathrm{IU} \text { for } 6 \pm 0.58 \\
\text { months }\end{array}$ & $\begin{array}{l}\text { Age (mean } \pm \text { SD): } 6.0 \\
\pm 3.8 \text { months (range: } \\
0.25-11 \text { months) }\end{array}$ & $\begin{array}{l}\text { Six boys-complete } \\
\text { testicular descent } \\
\text { Two boys-partial testicular } \\
\text { descent } \\
\text { One boy-testis } \\
\text { reascended } \\
\text { Testes gained normal size. }\end{array}$ & $\begin{array}{l}\mathrm{FSH}, \mathrm{LH} \text {, and testosterone } \\
\text { increased to normal range. }\end{array}$ \\
\hline
\end{tabular}

$\mathrm{CHH}$, congenital hypogonadotropic hypogonadism; r-hFSH, recombinant human $F S H$; $r h L H$, recombinant human $L H$.

boys experienced testicular re-ascent and needed orchiopexy $(244,245)$. In Greece, the boys were followed 3-10 years after treatment. At the last visit, all testes were still in the scrotal position, but the size measured by the Prader orchidometer was marginally reduced, from a mean of $1.5(1.0-2.5) \mathrm{mL}$ during treatment to $1.0(0.5-2.0) \mathrm{mL}$ at the last visit (244). In a small study in Finland, five $\mathrm{CHH}$ boys with cryptorchidism were treated with rhFSH and testosterone enanthate during infancy (242). All of them underwent orchiopexy at the age of 2.0 \pm 0.7 years. Serum inhibin B levels increased after starting the hormonal treatment and decreased after discontinuation of the treatment for $1.2 \pm 0.4$ months. During adolescence, the inhibin B levels were available in three boys (10.0-12.8 years of age), which were compared with six untreated $\mathrm{CHH}$ boys with a history of cryptorchidism (12.7-17.8 years of age). The inhibin $\mathrm{B}$ levels between these two groups were not different. The results of this study suggested a transient effect of the combined rhFSH and testosterone treatment on Sertoli cell function (242). Table 3 summarizes the studies on hormonal treatment during infancy in $\mathrm{CHH}$ boys with congenital cryptorchidism.

Overall, the data showed that gonadotropin administration during mini-puberty is relatively effective in inducing testicular descent in $\mathrm{CHH}$ patients. However, the available data are very limited and all of the studies are small due to the rarity of this condition. The European consensus statement on congenital hypogonadotropic hypogonadism published in 2015 recommends orchiopexy before the age of 1 year as the standard treatment for cryptorchidism (123), which is based mostly on the evidence from boys with isolated cryptorchidism, not in a specific subgroup of $\mathrm{CHH}$ boys (225). 


\section{UNANSWERED QUESTIONS AND FUTURE DIRECTIONS}

The cause of isolated cryptorchidism is still not fully understood, and therefore more studies investigating the mechanisms of cryptorchidism are still needed. The studies on hormonal treatment during mini-puberty in $\mathrm{CHH}$ boys showed promising results on testicular descent, however, the treatment outcomes were observed without randomization of the subjects. Additionally, long-term outcomes are still largely unknown. Therefore, randomized, multi-center studies that explore the role of gonadotropin or $\mathrm{GnRH}$ treatment in mini-puberty and peri-puberty in $\mathrm{CHH}$ patients with cryptorchidism are necessary to gain more knowledge on the effects of this treatment.

\section{CONCLUSION}

Hypogonadism can be a cause or effect of cryptorchidism. Conditions associated with decreased androgen levels or actions may present with unilateral or bilateral cryptorchidism. On the other hand, hypogonadism can be sequelae from cryptorchidism. Several studies have suggested that cryptorchidism, particularly bilateral cryptorchidism, is associated with reduced spermatogenesis and inhibin B levels and increased FSH levels in adulthood. Similar hormonal

\section{REFERENCES}

1. Foresta C, Zuccarello D, Garolla A, Ferlin A. Role of hormones, genes, and environment in human cryptorchidism. Endocr Rev. (2008) 29:560-80. doi: 10.1210/er.2007-0042

2. Virtanen HE, Toppari J. Epidemiology and pathogenesis of cryptorchidism. Hum Reprod Update. (2008) 14:49-58. doi: 10.1093/humupd/dmm027

3. Sijstermans K, Hack WW, Meijer RW, van der Voort-Doedens LM. The frequency of undescended testis from birth to adulthood: a review. Int $J$ Androl. (2008) 31:1-11. doi: 10.1111/j.1365-2605.2007.00770.x

4. Lee PA, Coughlin MT. Fertility after bilateral cryptorchidism. Evaluation by paternity, hormone, and semen data. Horm Res. (2001) 55:28-32. doi: 10.1159/000049960

5. Trabert B, Zugna D, Richiardi L, McGlynn KA, Akre O. Congenital malformations and testicular germ cell tumors. Int J cancer. (2013) 133:19004. doi: 10.1002/ijc.28207

6. Lip SZ, Murchison LE, Cullis PS, Govan L, Carachi R. A meta-analysis of the risk of boys with isolated cryptorchidism developing testicular cancer in later life. Arch Dis Child. (2013) 98:20-6. doi: 10.1136/archdischild-2012-302051

7. Walsh TJ, Dall'Era MA, Croughan MS, Carroll PR, Turek PJ. Prepubertal orchiopexy for cryptorchidism may be associated with lower risk of testicular cancer. J Urol. (2007) 178:1440-6. doi: 10.1016/j.juro.2007.05.166

8. Pettersson A, Richiardi L, Nordenskjold A, Kaijser M, Akre O. Age at surgery for undescended testis and risk of testicular cancer. N Engl J Med. (2007) 356:1835-41. doi: 10.1056/NEJMoa067588

9. Skakkebaek NE. Testicular dysgenesis syndrome: an increasingly common developmental disorder with environmental aspects. Hum Reprod. (2001) 16:972-8. doi: 10.1093/humrep/16.5.972

10. Skakkebaek NE, Rajpert-De Meyts E, Buck Louis GM, Toppari J, Andersson A, Eisenberg ML, et al. Male reproductive disorders and fertility trends: influences of environment and genetic susceptibility. Physiol Rev. (2016) 96:55-97. doi: 10.1152/physrev.00017.2015

11. Rey RA, Grinspon RP, Gottlieb S, Pasqualini T, Knoblovits P, Aszpis $\mathrm{S}$, et al. Male hypogonadism: an extended classification based on a findings have been observed during mini-puberty and puberty in some studies. Several studies have suggested reduced Leydig cell function during mini-puberty, at least in more severe forms of cryptorchidism. More studies are needed on the association between later testicular function, especially endocrine function, and operation age or type of cryptorchidism. Furthermore, studies exploring the underlying mechanisms of cryptorchidism that cause reduced testicular hormone production are needed. Lastly, more studies investigating predictors of hypogonadism in adulthood and interventions to reduce the risk of hypogonadism are necessary.

\section{AUTHOR CONTRIBUTIONS}

All the authors have contributed to writing of the review by providing texts and commenting the whole paper. They all take responsibility of the final manuscript.

\section{FUNDING}

This work was supported by the Academy of Finland (308065), Sigrid Juselius Foundation, Novo Nordisk Foundation, Special governmental funds for Turku University Hospital, Finnish Cultural Foundation, Jalmari and Rauha Ahokas Foundation, Kirsten and Freddy Johansen's Fund, and Juho Vainio Foundation.

developmental, endocrine physiology-based approach. Andrology. (2013) 1:3-16. doi: 10.1111/j.2047-2927.2012.00008.x

12. Lee PA. Fertility after cryptorchidism: epidemiology and other outcome studies. Urology. (2005) 66:427-31. doi: 10.1016/j.urology.2005.01.017

13. Virtanen HE, Toppari J. Cryptorchidism and fertility. Endocrinol Metab Clin North Am. (2015) 44:751-60. doi: 10.1016/j.ecl.2015.07.013

14. Boisen KA, Kaleva M, Main KM, Virtanen HE, Haavisto AM, Schmidt IM, et al. Difference in prevalence of congenital cryptorchidism in infants between two Nordic countries. Lancet. (2004) 363:1264-9. doi: 10.1016/S0140-6736(04)15998-9

15. Niedzielski JK, Oszukowska E, Słowikowska-Hilczer J. Undescended testis current trends and guidelines: a review of the literature. Arch Med Sci. (2016) 12:667-77. doi: 10.5114/aoms.2016.59940

16. Radmayr C, Dogan HS, Hoebeke P, Kocvara R, Nijman R, Stein R, et al. Management of undescended testes: European Association of Urology/European Society for Paediatric Urology Guidelines. J Pediatr Urol. (2016) 12:335-43. doi: 10.1016/j.jpurol.2016.07.014

17. Achermann JC, Hughes IA. Pediatric disorders of sex development. In: Melmed S, Polonsky KS, Larsen PR, Kronenberg HM, editors. Williams Textbook of Endocrinology. 13th ed. Philadelphia, PA: Elsevier (2016), p. 893-963.

18. Welsh M, Saunders PTK, Fisken M, Scott HM, Hutchison GR, Smith LB, et al. Identification in rats of a programming window for reproductive tract masculinization, disruption of which leads to hypospadias and cryptorchidism. J Clin Invest. (2008) 118:1479-90. doi: 10.1172/ JCI34241

19. Arboleda VA, Quigley CA, Vilain E. Genetic basis of gonadal and genital development. In: Jameson JL, De Groot LJ, de Kretser DM, Giudice LC, Grossman AB, Melmed S, et al., editors. Endocrinology: Adult \& Pediatrics. 7th ed. Philadelphia, PA: Elsevier Saunders (2016), p. 2051-85. doi: 10.1016/B978-0-323-18907-1.00118-9

20. del Valle I, Buonocore F, Duncan AJ, Lin L, Barenco M, Parnaik R, et al. A genomic atlas of human adrenal and gonad development. Wellcome Open Res. (2017) 2:25. doi: 10.12688/wellcomeopenres.11253.1 
21. Choi J, Smitz J. Luteinizing hormone and human chorionic gonadotropin: distinguishing unique physiologic roles. Gynecol Endocrinol. (2014) 30:17481. doi: 10.3109/09513590.2013.859670

22. Adham IM, Burkhardt E, Benahmed M, Engel W. Cloning of a cDNA for a novel insulin-like peptide of the testicular Leydig cells. J Biol Chem. (1993) 268:26668-72.

23. Hutson JM, Southwell BR, Li R, Lie G, Ismail K, Harisis G, et al. The regulation of testicular descent and the effects of cryptorchidism. Endocr Rev. (2013) 34:725-52. doi: 10.1210/er.2012-1089

24. Bay K, Main KM, Toppari J, Skakkebaek NE. Testicular descent: INSL3, testosterone, genes and the intrauterine milieu. Nat Rev Urol. (2011) 8:18796. doi: 10.1038/nrurol.2011.23

25. Ferlin A, Simonato M, Bartoloni L, Rizzo G, Bettella A, Dottorini T, et al. The INSL3-LGR8/GREAT ligand-receptor pair in human cryptorchidism. J Clin Endocrinol Metab. (2003) 88:4273-9. doi: 10.1210/jc.2003-030359

26. Lanciotti L, Cofini M, Leonardi A, Penta L, Esposito S. Up-to-date review about minipuberty and overview on hypothalamic-pituitary-gonadal axis activation in fetal and neonatal life. Front Endocrinol. (2018) 9:410. doi: 10.3389/fendo.2018.00410

27. Choi J, Smitz J. Luteinizing hormone and human chorionic gonadotropin: origins of difference. Mol Cell Endocrinol. (2014) 383:203-13. doi: 10.1016/j.mce.2013.12.009

28. Meroni SB, Galardo MN, Rindone G, Gorga A, Riera MF, Cigorraga SB. Molecular mechanisms and signaling pathways involved in Sertoli cell proliferation. Front Endocrinol. (2019) 10:224. doi: 10.3389/fendo.2019.00224

29. Grinspon RP, Rey RA. Anti-müllerian hormone and Sertoli cell function in paediatric male hypogonadism. Horm Res Paediatr. (2010) 73:81-92. doi: 10.1159/000277140

30. Rey RA. Mini-puberty and true puberty: differences in testicular function. Ann Endocrinol. (2014) 75:58-63. doi: 10.1016/j.ando.2014.03.001

31. Debieve F, Beerlandt S, Hubinont C, Thomas K. Gonadotropins, prolactin, inhibin $A$, inhibin $B$, and activin $A$ in human fetal serum from midpregnancy and term pregnancy. J Clin Endocrinol Metab. (2000) 85:2704. doi: $10.1210 /$ jcem.85.1.6249

32. Scott HM, Mason JI, Sharpe RM. Steroidogenesis in the fetal testis and its susceptibility to disruption by exogenous compounds. Endocr Rev. (2009) 30:883-925. doi: 10.1210/er.2009-0016

33. Codesal J, Regadera J, Nistal M, Regadera-Sejas J, Paniagua R. Involution of human fetal Leydig cells. An immunohistochemical, ultrastructural and quantitative study. J Anat. (1990) 172:103-14.

34. Cortes D, Müller J, Skakkebaek NE. Proliferation of Sertoli cells during development of the human testis assessed by stereological methods. Int J Androl. (1987) 10:589-96. doi: 10.1111/j.1365-2605.1987.tb 00358.x

35. Müller J, Skakkebaek NE. Fluctuations in the number of germ cells during the late foetal and early postnatal periods in boys. Acta Endocrinol. (1984) 105:271-4. doi: 10.1530/acta.0.1050271

36. Boas M, Boisen KA, Virtanen HE, Kaleva M, Suomi AM, Schmidt IM, et al. Postnatal penile length and growth rate correlate to serum testosterone levels: a longitudinal study of 1962 normal boys. Eur J Endocrinol. (2006) 154:125-9. doi: 10.1530/eje.1.02066

37. Koskenniemi JJ, Virtanen HE, Wohlfahrt-Veje C, Löyttyniemi E, Skakkebaek NE, Juul A, et al. Postnatal changes in testicular position are associated with IGF-I and function of Sertoli and Leydig cells. J Clin Endocrinol Metab. (2018) 103:1429-37. doi: 10.1210/jc.2017-01889

38. Kuiri-Hänninen T, Seuri R, Tyrväinen E, Turpeinen U, Hämäläinen E, Stenman UH, et al. Increased activity of the hypothalamic-pituitarytesticular axis in infancy results in increased androgen action in premature boys. J Clin Endocrinol Metab. (2011) 96:98-105. doi: 10.1210/jc.2010-1359

39. Lamminmäki A, Hines M, Kuiri-Hänninen T, Kilpeläinen L, Dunkel L, Sankilampi U. Testosterone measured in infancy predicts subsequent sex-typed behavior in boys and in girls. Horm Behav. (2012) 61:611-6. doi: 10.1016/j.yhbeh.2012.02.013

40. Main KM, Toppari J, Suomi AM, Kaleva M, Chellakooty M, Schmidt IM, et al. Larger testes and higher inhibin B levels in Finnish than in Danish newborn boys. J Clin Endocrinol Metab. (2006) 91:2732-7. doi: $10.1210 /$ jc. $2005-2443$
41. Bougnères P, François M, Pantalone L, Rodrigue D, Bouvattier C, Demesteere $\mathrm{E}$, et al. Effects of an early postnatal treatment of hypogonadotropic hypogonadism with a continuous subcutaneous infusion of recombinant follicle-stimulating hormone and luteinizing hormone. J Clin Endocrinol Metab. (2008) 93:2202-5. doi: 10.1210/jc.2008-0121

42. Kollin C, Stukenborg JB, Nurmio M, Sundqvist E, Gustafsson T, Söder $\mathrm{O}$, et al. Boys with undescended testes: endocrine, volumetric and morphometric studies on testicular function before and after orchidopexy at nine months or three years of age. J Clin Endocrinol Metab. (2012) 97:4588-95. doi: 10.1210/jc.2012-2325

43. Hadziselimovic F, Herzog B. Importance of early postnatal germ cell maturation for fertility of cryptorchid males. Horm Res Paediatr. (2001) 55:6-10. doi: 10.1159/000049956

44. Hadziselimovic F, Zivkovic D, Bica DT, Emmons LR, Diamond DA, Kogan SJ, et al. The importance of mini-puberty for fertility in cryptorchidism. $J$ Urol. (2005) 174:1536-9. doi: 10.1097/01.ju.0000181506.97839.b0

45. Yue SS, Hutson JM, Li R. Gene expression during gonocyte transformation into spermatogonial stem cells is not androgen dependent. J Pediatr Surg. (2015) 50:2090-3. doi: 10.1016/j.jpedsurg.2015.08.034

46. Mäkelä JA, Koskenniemi JJ, Virtanen HE, Toppari J. Testis development. Endocr Rev. (2019) 40:857-905. doi: 10.1210/er.2018-00140

47. Kuiri-Hänninen T, Sankilampi U, Dunkel L. Activation of the hypothalamicpituitary-gonadal axis in infancy: minipuberty. Horm Res Paediatr. (2014) 82:73-80. doi: 10.1159/000362414

48. Andersson AM, Toppari J, Haavisto AM, Petersen JH, Simell T, Simell O, et al. Longitudinal reproductive hormone profiles in infants: peak of inhibin B levels in infant boys exceeds levels in adult men. J Clin Endocrinol Metab. (1998) 83:675-81. doi: 10.1210/jc.83.2.675

49. Suomi AM, Main KM, Kaleva M, Schmidt IM, Chellakooty M, Virtanen HE, et al. Hormonal changes in 3-month-old cryptorchid boys. J Clin Endocrinol Metab. (2006) 91:953-8. doi: 10.1210/jc.2004-2318

50. Bay K, Virtanen HE, Hartung S, Ivell R, Main KM, Skakkebaek NE, et al. Insulin-like factor 3 levels in cord blood and serum from children: effects of age, postnatal hypothalamic-pituitary-gonadal axis activation, and cryptorchidism. J Clin Endocrinol Metab. (2007) 92:4020-7. doi: 10.1210/jc.2007-0974

51. Andersson AM, Skakkebæk NE. Serum inhibin B levels during male childhood and puberty. Mol Cell Endocrinol. (2001) 180:103-7. doi: 10.1016/S0303-7207(01)00520-2

52. Kelsey TW, Miles A, Mitchell RT, Anderson RA, Wallace WH. A normative model of serum inhibin B in young males. PLoS ONE. (2016) 11:e0153843. doi: 10.1371/journal.pone.0153843

53. Rey RA, Musse M, Venara M, Chemes HE. Ontogeny of the androgen receptor expression in the fetal and postnatal testis: its relevance on Sertoli cell maturation and the onset of adult spermatogenesis. Microsc Res Tech. (2009) 72:787-95. doi: 10.1002/jemt.20754

54. Josso N, Rey RA, Picard JY. Anti-müllerian hormone: a valuable addition to the toolbox of the pediatric endocrinologist. Int J Endocrinol. (2013) 2013:674105. doi: 10.1155/2013/674105

55. Xu H-Y, Zhang H-X, Xiao Z, Qiao J, Li R. Regulation of antiMüllerian hormone $(\mathrm{AMH})$ in males and the associations of serum AMH with the disorders of male fertility. Asian J Androl. (2019) 21:109-14. doi: 10.4103/aja.aja_83_18

56. Valeri C, Schteingart HF, Rey RA. The prepubertal testis: biomarkers and functions. Curr Opin Endocrinol Diabetes Obes. (2013) 20:224-33. doi: 10.1097/MED.0b013e328360be2c

57. Edelsztein NY, Grinspon RP, Schteingart HF, Rey RA. Anti-Müllerian hormone as a marker of steroid and gonadotropin action in the testis of children and adolescents with disorders of the gonadal axis. Int J Pediatr Endocrinol. (2016) 2016:20. doi: 10.1186/s13633-016-0038-2

58. Andersson AM, Müller J, Skakkebæk NE. Different roles of prepubertal and postpubertal germ cells and Sertoli cells in the regulation of serum inhibin B levels. J Clin Endocrinol Metab. (1998) 83:4451-8. doi: 10.1210/jc.83.12.4451

59. Aksglaede L, Sørensen K, Boas M, Mouritsen A, Hagen CP, Jensen RB, et al. Changes in anti-Müllerian hormone (AMH) throughout the life span: a population-based study of 1027 healthy males from birth (cord blood) to the age of 69 years. J Clin Endocrinol Metab. (2010) 95:5357-64. doi: $10.1210 /$ jc. $2010-1207$ 
60. Josso N, Lamarre I, Picard JY, Berta P, Davies N, Morichon N, et al. AntiMüllerian hormone in early human development. Early Hum Dev. (1993) 33:91-9. doi: 10.1016/0378-3782(93)90204-8

61. Guibourdenche J, Lucidarme N, Chevenne D, Rigal O, Nicolas M, Luton $\mathrm{D}$, et al. Anti-Müllerian hormone levels in serum from human foetuses and children: pattern and clinical interest. Mol Cell Endocrinol. (2003) 211:55-63. doi: 10.1016/j.mce.2003.09.011

62. Edelsztein NY, Rey RA. Importance of the androgen receptor signaling in gene transactivation and transrepression for pubertal maturation of the testis. Cells. (2019) 8:861. doi: 10.3390/cells8080861

63. Boukari K, Meduri G, Brailly-Tabard S, Guibourdenche J, Ciampi ML, Massin N, et al. Lack of androgen receptor expression in Sertoli cells accounts for the absence of anti-Mullerian hormone repression during early human testis development. J Clin Endocrinol Metab. (2009) 94:1818-25. doi: 10.1210/jc.2008-1909

64. Willems A, Batlouni SR, Esnal A, Swinnen JV, Saunders PT, Sharpe $\mathrm{RM}$, et al. Selective ablation of the androgen receptor in mouse Sertoli cells affects Sertoli cell maturation, barrier formation and cytoskeletal development. PLoS ONE. (2010) 5:14168. doi: 10.1371/journal.pone.00 14168

65. Young J, Rey R, Couzinet B, Chanson P, Josso N, Schaison G. Antimüllerian hormone in patients with hypogonadotropic hypogonadism. J Clin Endocrinol Metab. (1999) 84:2696-9. doi: 10.1210/jcem.84.8.5972

66. Anawalt BD, Bebb RA, Matsumoto AM, Groome NP, Illingworth PJ, McNeilly AS, et al. Serum inhibin B levels reflect Sertoli cell function in normal men and men with testicular dysfunction. J Clin Endocrinol Metab. (1996) 81:3341-5. doi: 10.1210/jcem.81.9.8784094

67. Ivell R, Heng K, Anand-Ivell R. Insulin-like factor 3 and the HPG axis in the male. Front Endocrinol. (2014) 5:1-7. doi: 10.3389/fendo.2014.00006

68. Bay K, Hartung S, Ivell R, Schumacher M, Jürgensen D, Jorgensen N, et al. Insulin-like factor 3 serum levels in 135 normal men and 85 men with testicular disorders: relationship to the luteinizing hormone-testosterone axis. J Clin Endocrinol Metab. (2005) 90:3410-8. doi: 10.1210/jc.2004-2257

69. Jensen TK, Andersson AM, Hjollund NH, Scheike T, Kolstad H, Giwercman $\mathrm{A}$, et al. Inhibin $\mathrm{B}$ as a serum marker of spermatogenesis: correlation to differences in sperm concentration and follicle-stimulating hormone levels. A study of 349 Danish men. J Clin Endocrinol Metab. (1997) 82:4059-63. doi: 10.1210/jcem.82.12.4456

70. Pierik FH, Vreeburg JT, Stijnen T, De Jong FH, Weber RF. Serum inhibin B as a marker of spermatogenesis. J Clin Endocrinol Metab. (1998) 83:3110-4. doi: $10.1210 /$ jcem.83.9.5121

71. Cortes D, Clasen-Linde E, Hutson JM, Li R, Thorup J. The Sertoli cell hormones inhibin-B and anti Müllerian hormone have different patterns of secretion in prepubertal cryptorchid boys. J Pediatr Surg. (2016) 51:475-80. doi: 10.1016/j.jpedsurg.2015.08.059

72. Crofton PM, Illingworth PJ, Groome NP, Stirling HF, Swanston I, Gow S, et al. Changes in dimeric inhibin A and B during normal early puberty in boys and girls. Clin Endocrinol. (1997) 46:109-14. doi: 10.1046/j.1365-2265.1997.d01-1744.x

73. Coughlin MT, Bellinger MF, Lee PA. Age at unilateral orchiopexy: effect on hormone levels and sperm count in adulthood. J Urol. (1999) 162:986-8. doi: 10.1097/00005392-199909000-00002

74. Toppari J, Kaleva M, Virtanen HE, Main KM, Skakkebæk NE. Luteinizing hormone in testicular descent. Mol Cell Endocrinol. (2007) 269:34-7. doi: 10.1016/j.mce.2006.10.021

75. Virtanen HE, Toppari J. Embryology and physiology of testicular development and descent. Pediatr Endocrinol Rev. (2014) 11(Suppl 2):206-13.

76. Rey R, Josso N, Racine C. Sexual differentiation. In: Feingold KR, Anawalt B, Boyce A, et al., editors. Endotext [Internet]. South Dartmouth, MA: MDText.com, Inc. (2000).

77. Bouzada J, Vázquez T, Duran M, Delmas V, Larkin T, Cuesta MA, et al. New insights into the morphogenesis of the gubernaculum testis and the inguinal canal. Clin Anat. (2017) 30:599-607. doi: 10.1002/ca. 22880

78. Hadziselimovic F. On the descent of the epididymo-testicular unit, cryptorchidism, and prevention of infertility. Basic Clin Androl. (2017) 27:21. doi: $10.1186 /$ s12610-017-0065-8
79. Nef S, Parada LF. Cryptorchidism in mice mutant for Insl3. Nat Genet. (1999) 22:295-9. doi: 10.1038/10364

80. Zimmermann S, Steding G, Emmen JM, Brinkmann AO, Nayernia $\mathrm{K}$, Holstein $\mathrm{AF}$, et al. Targeted disruption of the Insl3 gene causes bilateral cryptorchidism. Mol Endocrinol. (1999) 13:681-91. doi: 10.1210/mend.13.5.0272

81. Gorlov IP, Kamat A, Bogatcheva N V, Jones E, Lamb DJ, Truong A, et al. Mutations of the GREAT gene cause cryptorchidism. Hum Mol Genet. (2002) 11:2309-18. doi: 10.1093/hmg/11.19.2309

82. Shono T, Ramm-Anderson S, Hutson JM. Transabdominal testicular descent is really ovarian ascent. J Urol. (1994) 152(2 Part 2):781-4. doi: 10.1016/S0022-5347(17)32708-8

83. Spencer JR, Torrado T, Sanchez RS, Vaughan ED, Imperato-MperatoMcginley J. Effects of flutamide and finasteride on rat testicular descent. Endocrinology. (1991) 129:741-8. doi: 10.1210/endo-129-2-741

84. Hutson JM, Lopez-Marambio FA. The possible role of AMH in shortening the gubernacular cord in testicular descent: a reappraisal of the evidence. $J$ Pediatr Surg. (2017) 52:1656-60. doi: 10.1016/j.jpedsurg.2017.05.021

85. Heyns CF. The gubernaculum during testicular descent in the human fetus. J Anat. (1987) 153:93-112.

86. Barteczko KJ, Jacob MI. The testicular descent in human. Origin, development and fate of the gubernaculum Hunteri, processus vaginalis peritonei, and gonadal ligaments. Adv Anat Embryol Cell Biol. (2000) 156:198. doi: 10.1007/978-3-642-58353-7

87. Cendron M, Huff DS, Keating MA, Snyder HM, Duckett JW. Anatomical, morphological and volumetric analysis: a review of 759 cases of testicular maldescent. J Urol. (1993) 149:570-3. doi: 10.1016/S0022-5347(17)36151-7

88. Hutson JM, Nation T, Balic A, Southwell BR. The role of the gubernaculum in the descent and undescent of the testis. Ther Adv Urol. (2009) 1:115-21. doi: $10.1177 / 1756287209105266$

89. Hutson JM. Testicular feminization: a model for testicular descent in mice and men. J Pediatr Surg. (1986) 21:195-8. doi: 10.1016/S0022-3468(86)80830-2

90. Barthold JS, Kumasi-Rivers K, Upadhyay J, Shekarriz B, Imperato-Mcginley J. Testicular position in the androgen insensitivity syndrome: implications for the role of androgens in testicular descent. J Urol. (2000) 164:497-501. doi: 10.1016/S0022-5347(05)67411-3

91. Wilson JD. Sexual differentiation. Annu Rev Physiol. (1978) 40:279-306. doi: 10.1146/annurev.ph.40.030178.001431

92. Hughes IA. Minireview: sex differentiation. Endocrinology. (2001) 142:32817. doi: 10.1210/endo.142.8.8406

93. Yuan FP, Li X, Lin J, Schwabe C, Büllesbach EE, Rao CV, et al. The role of RXFP2 in mediating androgen-induced inguinoscrotal testis descent in LH receptor knockout mice. Reproduction. (2010) 139:759-69. doi: 10.1530/REP-09-0518

94. Berkowitz GS, Lapinski RH, Dolgin SE, Gazella JG, Bodian CA, Holzman IR. Prevalence and natural history of cryptorchidism. Pediatrics. (1993) 92:44-9.

95. John Radcliffe Hospital Cryptorchidism Study Group. Cryptorchidism: a prospective study of 7500 consecutive male births, 1984-8. Arch Dis Child. (1992) 67:892-9. doi: 10.1136/adc.67.7.892

96. Scorer CG. The descent of the testis. Arch Dis Child. (1964) 39:605-9. doi: 10.1136/adc.39.208.605

97. Wohlfahrt-Veje C, Boisen KA, Boas M, Damgaard IN, Kai CM, Schmidt IM, et al. Acquired cryptorchidism is frequent in infancy and childhood. Int $J$ Androl. (2009) 32:423-8. doi: 10.1111/j.1365-2605.2008.00946.x

98. Acerini CL, Miles HL, Dunger DB, Ong KK, Hughes IA. The descriptive epidemiology of congenital and acquired cryptorchidism in a UK infant cohort. Arch Dis Child. (2009) 94:868-72. doi: 10.1136/adc.2008.150219

99. Promm M, Schröder A, Neissner C, Eder F, Rösch WH, Schröder J. Acquired cryptorchidism: more harm than thought? J Pediatr Urol. (2016) 12:236.e1-6. doi: 10.1016/j.jpurol.2016.04.010

100. Hack WW, Goede J, van der Voort-Doedens LM, Meijer RW. Acquired undescended testis: putting the pieces together. Int J Androl. (2012) 35:41-5. doi: 10.1111/j.1365-2605.2011.01155.x

101. Hutson JM, Balic A, Nation T, Southwell B. Cryptorchidism. Semin Pediatr Surg. (2010) 19:215-24. doi: 10.1053/j.sempedsurg.2010.04.001

102. Ratcliffe S. Long term outcome in children of sex chromosome abnormalities. Arch Dis Child. (1999) 80:192-5. doi: 10.1136/adc.80.2.192 
103. Lanfranco F, Kamischke A, Zitzmann M, Nieschlag E. Klinefelter's syndrome. Lancet. (2004) 364:273-83. doi: 10.1016/S0140-6736(04)16678-6

104. Cunha SC, Andrade JGR de, Angelis CM de, Billis A, Bustorff-Silva JM, Maciel-Guerra AT, et al. Early development of a gonadal tumor in a patient with mixed gonadal dysgenesis. Arch Endocrinol Metab. (2018) 62:644-7. doi: 10.20945/2359-3997000000091

105. Aruna N, Purushottam Rao M, Rajangam S. 46, XX/46, XY chimerism-a case report. J Anat Soc India. (2006) 55:24-6.

106. Audí L, Ahmed SF, Krone N, Cools M, McElreavey K, Holterhus PM, et al. Genetics in endocrinology: approaches to molecular genetic diagnosis in the management of differences/disorders of sex development (DSD): position paper of EU COST action BM 1303 "DSDnet." Eur J Endocrinol. (2018) 179:R197-206. doi: 10.1530/EJE-18-0256

107. McElreavey K, Jorgensen A, Eozenou C, Merel T, Bignon-Topalovic J, Tan DS, et al. Pathogenic variants in the DEAH-box RNA helicase DHX37 are a frequent cause of 46,XY gonadal dysgenesis and 46,XY testicular regression syndrome. Genet Med. (2019). doi: 10.1038/s41436-019-0606-y. [Epub ahead of print].

108. Swee DS, Quinton R. Congenital hypogonadotrophic hypogonadism: minipuberty and the case for neonatal diagnosis. Front Endocrinol. (2019) 10:97. doi: 10.3389/fendo.2019.00097

109. Ferreira L, Silveira G, Latronico AC. Approach to the patient with hypogonadotropic hypogonadism. J Clin Endocrinol Metab. (2014) 98:17818. doi: 10.1210/jc.2012-3550

110. Vizeneux A, Hilfiger A, Bouligand J, Pouillot M, Brailly-Tabard S, Bashamboo A, et al. Congenital hypogonadotropic hypogonadism during childhood: presentation and genetic analyses in 46 boys. PLoS ONE. (2013) 8:e77827. doi: 10.1371/journal.pone.0077827

111. Hsu P, Ma A, Wilson M, Williams G, Curotta J, Munns CF, et al. CHARGE syndrome: a review. J Paediatr Child Health. (2014) 50:504-11. doi: 10.1111/jpc.12497

112. Chew G, Hutson JM. Incidence of cryptorchidism and ascending testes in Trisomy 21: a 10 year retrospective review. Pediatr Surg Int. (2004) 20:744-7. doi: 10.1007/s00383-004-1290-8

113. Sharland M, Burch M, McKenna WM, Paton MA. A clinical study of Noonan syndrome. Arch Dis Child. (1992) 67:178-83. doi: 10.1136/adc.67.2.178

114. Digilio M, Marino B. Clinical manifestations of Noonan syndrome. Images Paediatr Cardiol. (2001) 3:19-30.

115. Roberts AE, Allanson JE, Tartaglia M, Gelb BD. Noonan syndrome. Lancet. (2013) 381:333-42. doi: 10.1016/S0140-6736(12)61023-X

116. Cassidy SB, Schwartz S, Miller JL, Driscoll DJ. Prader-Willi syndrome. Genet Med. (2012) 14:10-26. doi: 10.1038/gim.0b013e31822bead0

117. Siemensma EP, de Lind van Wijngaarden RF, Otten BJ, de Jong FH, Hokken-Koelega AC. Testicular failure in boys with prader-willi syndrome: longitudinal studies of reproductive hormones. J Clin Endocrinol Metab. (2012) 97:E452-9. doi: 10.1210/jc.2011-1954

118. Moore SJ, Green JS, Fan Y, Bhogal AK, Dicks E, Fernandez BA, et al. Clinical and genetic epidemiology of Bardet-Biedl syndrome in Newfoundland: a 22year prospective, population-based, cohort study. Am J Med Genet A. (2005) 132A:352-60. doi: 10.1002/ajmg.a.30406

119. Beales PL, Elcioglu N, Woolf AS, Parker D, Flinter FA. New criteria for improved diagnosis of Bardet-Biedl syndrome: results of a population survey. J Med Genet. (1999) 36:437-46.

120. Urh K, Kolenc Ž, Hrovat M, Svet L, Dovč P, Kunej T. Molecular mechanisms of syndromic cryptorchidism: data synthesis of 50 studies and visualization of gene-disease network. Front Endocrinol. (2018) 9:1-11. doi: $10.3389 /$ fendo.2018.00425

121. Virtanen HE, Bjerknes R, Cortes D, Jørgensen N, Rajpert-De Meyts E, Thorsson AV, et al. Cryptorchidism: classification, prevalence and long-term consequences. Acta Paediatr. (2007) 96:611-6. doi: 10.1111/j.1651-2227.2007.00241.x

122. Hughes IA, Houk C, Ahmed SF, Lee PA. Consensus statement on management of intersex disorders. J Pediatr Urol. (2006) 2:148-62. doi: 10.1016/j.jpurol.2006.03.004

123. Boehm U, Bouloux PM, Dattani MT, De Roux N, Dodé C, Dunkel L, et al. Expert consensus document: European Consensus Statement on congenital hypogonadotropic hypogonadism-pathogenesis, diagnosis and treatment. Nat Rev Endocrinol. (2015) 11:547-64. doi: 10.1038/nrendo.2015.112
124. Main KM, Skakkebaek NE, Toppari J. Cryptorchidism as part of the testicular dysgenesis syndrome: the environmental connection. Endocr Dev. (2009) 14:167-73. doi: $10.1159 / 000207485$

125. Davis SM, Rogol AD, Ross JL. Testis development and fertility potential in boys with klinefelter syndrome. Endocrinol Metab Clin North Am. (2015) 44:843-65. doi: 10.1016/j.ecl.2015.07.008

126. Fechner PY, Marcantonio SM, Ogata T, Rosales TO, Smith KD, Goodfellow PN, et al. Report of a kindred with X-linked (or autosomal dominant sexlimited) 46,XY partial gonadal dysgenesis. J Clin Endocrinol Metab. (1993) 76:1248-53. doi: 10.1210/jcem.76.5.8496317

127. Baetens D, Verdin H, De Baere E, Cools M. Update on the genetics of differences of sex development (DSD). Best Pract Res Clin Endocrinol Metab. (2019) 33:101271. doi: 10.1016/j.beem.2019.04.005

128. Laitinen EM, Tommiska J, Virtanen HE, Oehlandt H, Koivu R, Vaaralahti $\mathrm{K}$, et al. Isolated cryptorchidism: no evidence for involvement of genes underlying isolated hypogonadotropic hypogonadism. Mol Cell Endocrinol. (2011) 341:35-8. doi: 10.1016/j.mce.2011.05.015

129. Montenegro LR, Silveira LF, Tusset C, De Castro M, Versiani BR, Latronico AC, et al. Combined use of multiplex ligation-dependent probe amplification and automatic sequencing for identification of KAL1 defects in patients with Kallmann syndrome. Fertil Steril. (2013) 100:854-9. doi: 10.1016/j.fertnstert.2013.04.045

130. Achiron R, Pinhas-Hamiel O, Zalel Y, Rotstein Z, Lipitz S. Development of fetal male gender: prenatal sonographic measurement of the scrotum and evaluation of testicular descent. Ultrasound Obstet Gynecol. (1998) 11:242-5. doi: 10.1046/j.1469-0705.1998.11040242.x

131. Sampaio FJ, Favorito LA. Analysis of testicular migration during the fetal period in humans. J Urol. (1998) 159:540-2. doi: 10.1016/S0022-5347(01)63980-6

132. Rotondi M, Valenzano F, Bilancioni E, Spanò G, Rotondi M, Giorlandino C. Prenatal measurement of testicular diameter by ultrasonography: development of fetal male gender and evaluation of testicular descent. Prenat Diagn. (2001) 21:112-5. doi: 10.1002/1097-0223(200102)21:2<112::AID-PD2>3.0.CO;2-1

133. Main KM, Schmidt IM, Skakkebaek NE. A possible role for reproductive hormones in newborn boys: progressive hypogonadism without the postnatal testosterone peak. J Clin Endocrinol Metab. (2000) 85:4905-7. doi: $10.1210 /$ jcem. 85.12 .7058

134. Crinò A, Schiaffini R, Ciampalini P, Spera S, Beccaria L, Benzi F, et al. Hypogonadism and pubertal development in Prader-Willi syndrome. Eur J Pediatr. (2003) 162:327-33. doi: 10.1007/s00431-002-1132-4

135. Picard J-Y, Cate RL, Racine C, Josso N. The persistent Müllerian duct syndrome: an update based upon a personal experience of 157 cases. Sex Dev. (2017) 11:109-25. doi: 10.1159/000475516

136. Behringer RR, Finegold MJ, Cate RL. Müllerian-inhibiting substance function during mammalian sexual development. Cell. (1994) 79:415-25. doi: 10.1016/0092-8674(94)90251-8

137. Massart F, Saggese G. Morphogenetic targets and genetics of undescended testis. Sex Dev. (2010) 4:326-35. doi: 10.1159/000321006

138. Mamoulakis C, Georgiou I, Dimitriadis F, Tsounapi P, Giannakis I, Chatzikyriakidou A, et al. Genetic analysis of the human Insulin-like 3 gene: absence of mutations in a Greek paediatric cohort with testicular maldescent. Andrologia. (2014) 46:986-96. doi: 10.1111/and.12184

139. Ferlin A, Zuccarello D, Garolla A, Selice R, Vinanzi C, Ganz F, et al. Mutations in INSL3 and RXFP2 genes in cryptorchid boys. Ann N Y Acad Sci. (2009) 1160:213-4. doi: 10.1111/j.1749-6632.2008.03784.x

140. Burgt I van der. Noonan syndrome. Orphanet J Rare Dis. (2007) 2:4. doi: 10.1186/1750-1172-2-4

141. Damgaard IN, Jensen TK, Petersen JH, Skakkebæk NE, Toppari J, Main $\mathrm{KM}$, et al. Risk factors for congenital cryptorchidism in a prospective birth cohort study. PLoS ONE. (2008) 3:e3051. doi: 10.1371/journal.pone. 0003051

142. Gurney JK, McGlynn KA, Stanley J, Merriman T, Signal V, Shaw C, et al. Risk factors for cryptorchidism. Nat Rev Urol. (2017) 14:534-48. doi: 10.1038/nrurol.2017.90

143. Juul A, Almstrup K, Andersson AM, Jensen TK, Jørgensen N, Main KM, et al. Possible fetal determinants of male infertility. Nat Rev Endocrinol. (2014) 10:553-62. doi: 10.1038/nrendo.2014.97 
144. Damstra T, Barlow S, Bergman A, Kavlock R, Van Der Kraak G. Global Assessment of the State-of-the-Science of Endocrine Disrupters. Geneva: World Health Organization (2002), p. 1.

145. Virtanen HE, Adamsson A. Cryptorchidism and endocrine disrupting chemicals. Mol Cell Endocrinol. (2012) 355:208-20. doi: 10.1016/j.mce.2011.11.015

146. Toppari J, Larsen JC, Christiansen P, Giwercman A, Grandjean P, Guillette LJ, et al. Male reproductive health and environmental xenoestrogens. Environ Health Perspect. (1996) 104(suppl 4):741-803. doi: 10.2307/ 3432709

147. Rajpert-De Meyts E. Developmental model for the pathogenesis of testicular carcinoma in situ: genetic and environmental aspects. Hum Reprod Update. (2006) 12:303-23. doi: 10.1093/humupd/dmk006

148. Martin OV, Shialis T, Lester JN, Scrimshaw MD, Boobis AR, Voulvoulis N. Testicular dysgenesis syndrome and the estrogen hypothesis: a quantitative meta-analysis. Environ Health Perspect. (2008) 116:149-57. doi: 10.1289/ehp.10545

149. Virtanen H, Main K, Toppari J. Association of endocrine disrupting chemicals with male reproductive health. In: Huhtaniemi I, editor. Encyclopedia of Endocrine Diseases. 2nd ed. Kidlington, UK; Cambridge, MA: Oxford Academic Press; Elsevier Inc. (2019), p. 802-11. doi: 10.1016/B978-0-12-801238-3.64345-3

150. Huff DS, Hadziselimovic F, Snyder HM, Duckett JW, Keating MA. Postnatal testicular maldevelopment in unilateral cryptorchidism. J Urol. (1989) 142(2 Pt 2):546-8. doi: 10.1016/S0022-5347(17)38811-0

151. Dunkel L, Hirvonen V, Erkkilä K. Clinical aspects of male germ cell apoptosis during testis development and spermatogenesis. Cell Death Differ. (1997) 4:171-9. doi: 10.1038/sj.cdd.4400234

152. Hadziselimovic F, Thommen L, Girard J, Herzog B. The significance of postnatal gonadotropin surge for testicular development in normal and cryptorchid testes. J Urol. (1986) 136(1 Part 2):274-6. doi: 10.1016/S0022-5347(17)44839-7

153. Huff DS, Hadziselimovic F, Snyder HM, Blyth B, Duckett JW. Early postnatal testicular maldevelopment in cryptorchidism. J Urol. (1991) 146(2 Part 2):624-6. doi: 10.1016/S0022-5347(17)37874-6

154. Huff DS, Fenig DM, Canning DA, Carr MC, Zderic SA, Snyder HM 3rd. Abnormal germ cell development in cryptorchidism. Horm Res Paediatr. (2001) 55:11-7. doi: 10.1159/000049957

155. Suskind A, Hayner-Buchan A, Feustel PJ, Kogan BA. Fibrosis correlates with detailed histological analysis of human undescended testes. BJU Int. (2008) 101:1441-5. doi: 10.1111/j.1464-410X.2007.07406.x

156. Park KH, Lee JH, Han JJ, Lee SD, Song SY. Histological evidences suggest recommending orchiopexy within the first year of life for children with unilateral inguinal cryptorchid testis. Int J Urol. (2007) 14:616-21. doi: 10.1111/j.1442-2042.2007.01788.x

157. Fénichel P, Lahlou N, Coquillard P, Panaïa-Ferrari P, Wagner-Mahler $\mathrm{K}$, Brucker-Davis F. Cord blood Insulin-like peptide 3 (INSL3) but not testosterone is reduced in idiopathic cryptorchidism. Clin Endocrinol. (2015) 82:242-7. doi: 10.1111/cen.12500

158. Gendrel D, Roger M, Job JC. Plasma gonadotropin and testosterone values in infants with cryptorchidism. J Pediatr. (1980) 97:217-20. doi: 10.1016/S0022-3476(80)80477-X

159. Baker BA, Morley R, Lucas A. Plasma testosterone in preterm infants with Cryptorchidism. Arch Dis Child. (1988) 63:1198-200. doi: 10.1136/adc.63.10.1198

160. De Muinck Keizer-Schrama SM, Hazebroek FW, Drop SL, Degenhart HJ, Molenaar JC, Visser HK. Hormonal evaluation of boys born with undescended testes during their first year of life. J Clin Endocrinol Metab. (1988) 66:159-64. doi: 10.1210/jcem-66-1-159

161. Hamza AF, Elrahim M, Elnagar O, Maaty SA, Bassiouny IE, Jehannin B. Testicular descent: when to interfere? Eur J Pediatr Surg. (2001) 11:173-6. doi: 10.1055/s-2001-15484

162. Raivio T, Toppari J, Kaleva M, Virtanen H, Haavisto AM, Dunkel L, et al. Serum androgen bioactivity in cryptorchid and noncryptorchid boys during the postnatal reproductive hormone surge. J Clin Endocrinol Metab. (2003) 88:2597-9. doi: 10.1210/jc.2002-021676

163. Barthold JS, Manson J, Regan V, Si X, Hassink SG, Coughlin MT, et al. Reproductive hormone levels in infants with cryptorchidism during postnatal activation of the pituitary-testicular axis. J Urol. (2004) 172:173641. doi: 10.1097/01.ju.0000138523.24337.be

164. Pierik FH, Deddens JA, Burdorf A, de Muinck Keizer-Schrama SM, Jong FH, Weber RF. The hypothalamus-pituitary-testis axis in boys during the first six months of life: a comparison of cryptorchidism and hypospadias cases with controls. Int J Androl. (2009) 32:453-61. doi: $10.1111 / \mathrm{j} .1365-2605.2008 .00877 . \mathrm{x}$

165. Gendrel D, Roger M, Chaussain JL, Canlorbe P, Job JC. Correlation of pituitary and testicular responses to stimulation tests in cryptorchid children. Acta Endocrinol. (1977) 86:641-50. doi: 10.1530/acta.0.0860641

166. Longui CA, Arnhold IJ, Mendonca BB, D’Osvaldo AF, Bloise W. Serum inhibin levels before and after gonadotropin stimulation in cryptorchid boys under age 4 years. J Pediatr Endocrinol Metab. 11:687-92. doi: 10.1515/JPEM.1998.11.6.687

167. Christiansen P, Anderson AM, Skakkebæk NE, Juul A. Serum inhibin B, FSH, $\mathrm{LH}$ and testosterone levels before and after human chorionic gonadotropin stimulation in prepubertal boys with cryptorchidism. Eur J Endocrinol. (2002) 147:95-101. doi: 10.1530/eje.0.1470095

168. Iwatsuki S, Kojima Y, Mizuno K, Kamisawa H, Umemoto Y, Sasaki S, et al. Endocrine assessment of prepubertal boys with a history of cryptorchidism and/or hypospadias: a pilot study. J Urol. (2011) 185(6S):2444-50. doi: 10.1016/j.juro.2011.01.018

169. Komarowska MD, Milewski R, Charkiewicz R, Matuszczak E, Sulewska A, Zelazowska-Rutkowska B, et al. Are anti-Müllerian hormone and its receptor polymorphism associated with the hormonal condition of undescended testes? Adv Med Sci. (2016) 61:288-92. doi: 10.1016/j.advms.2016.03.004

170. Hamdi SM, Almont T, Galinier P, Mieusset R, Thonneau P. Altered secretion of Sertoli cells hormones in 2-year-old prepubertal cryptorchid boys: a cross-sectional study. Andrology. (2017) 5:783-9. doi: 10.1111/andr.12373

171. Grinspon RP, Gottlieb S, Bedecarrás P, Rey RA. Anti-Müllerian hormone and testicular function in prepubertal boys with cryptorchidism. Front Endocrinol. (2018) 9:182. doi: 10.3389/fendo.2018.00182

172. Dickerman Z, Topper E, Dintsman M, Zer M, Prager-Lewin R, Kaufman H, et al. Pituitary-gonadal function, pubertal development and sperm counts in cryptorchidism: a longitudinal study. Pediat Adolesc Endocr. (1979) 6:195214.

173. de Gouveia Brazao CA, Pierik FH, Erenpreiss Y, de Jong FH, Dohle GR, Weber RFA. The effect of cryptorchidism on inhibin $\mathrm{B}$ in a subfertile population. Clin Endocrinol. (2003) 59:136-41. doi: 10.1046/j.1365-2265.2003.01813.x

174. Andersson AM, Jørgensen N, Frydelund-Larsen L, Rajpert-De Meyts E, Skakkebæk NE. Impaired Leydig cell function in infertile men: a study of 357 idiopathic infertile men and 318 proven fertile controls. J Clin Endocrinol Metab. (2004) 89:3161-7. doi: 10.1210/jc.2003-031786

175. Rohayem J, Luberto A, Nieschlag E, Zitzmann M, Kliesch S. Delayed treatment of undescended testes may promote hypogonadism and infertility. Endocrine. (2017) 55:914-24. doi: 10.1007/s12020-0161178-0

176. Kuiri-hänninen T, Koskenniemi J, Dunkel L, Toppari J, Quinton R. Postnatal testicular activity in healthy boys and boys with cryptorchidism. Front Endocrinol. (2019) 10:1-12. doi: 10.3389/fendo.2019.00489

177. Job JC, Toublanc JE, Chaussain JL, Gendrel D, Roger M, Canlorbe P. The pituitary-gonadal axis in cryptorchid infants and children. Eur J Pediatr. (1987) 146(Suppl):S2-5. doi: 10.1007/BF00452857

178. Raivio T, Palvimo JJ, Dunkel L, Wickman S, Jänne OA. Novel assay for determination of androgen bioactivity in human serum. J Clin Endocrinol Metab. (2001) 86:1539-44. doi: 10.1210/jcem.86.4.7329

179. Bertelloni S, Russo G, Baroncelli GI. Human chorionic gonadotropin test: old uncertainties, new perspectives, and value in $46, \mathrm{XY}$ disorders of sex development. Sex Dev. (2018) 12:41-9. doi: 10.1159/000 481552

180. Kubini K, Zachmann M, Albers N, Hiort O, Bettendorf M, Wölfle J, et al. Basal inhibin $\mathrm{B}$ and the testosterone response to human chorionic gonadotropin correlate in prepubertal boys. J Clin Endocrinol Metab. (2000) 85:134-8. doi: $10.1210 /$ jc. 85.1 .134

181. Winters SJ. Laboratory assessment of testicular function. In: Feingold KR, Anawalt B, Boyce A, et al., editors. Endotext [Internet]. South Dartmouth, MA: MDText.com, Inc. (2000). 
182. Cavallo A, Zhou XH. LHRH test in the assessment of puberty in normal children. Horm Res Paediatr. (1994) 41:10-5. doi: 10.1159/000183870

183. Brook CGD, Brown RS, editors. Tests and normal values in pediatric endocrinology. In: Handbook of Clinical Pediatric Endocrinology. 1st ed. Blackwell Publishing (2008), p. 214-37.

184. Nakamoto J. Endocrine testing. In: Jameson JL, De Groot LJ, de Kretser DM, Giudice LC, Grossman AB, Melmed S, et al., editors. Endocrinology: Adult \& Pediatric. 7th ed. Elsevier Saunders (2016), p. 2683.

185. Haavisto A-M, Dunkel L, Pettersson K, Huhtaniemi I. LH measurements by in vitro bioassay and a highly sensitive immunofluorometric assay improve the distinction between boys with constitutional delay of puberty and hypogonadotropic hypogonadism. Pediatr Res. (1990) 27:3-6. doi: 10.1203/00006450-199003000-00002

186. Grumbach M. A window of opportunity: the diagnosis of gonadotropin deficiency in the male infant. J Clin Endocrinol Metab. (2005) 90:3122-7. doi: $10.1210 /$ jc. $2004-2465$

187. Biro FM, Lucky AW, Huster GA, Morrison JA. Pubertal staging in boys. J Pediatr. (1995) 127:100-2. doi: 10.1016/S0022-3476(95)70265-2

188. Palmert MR, Dunkel L. Delayed Puberty. N Engl J Med. (2012) 366:443-53. doi: 10.1056/NEJMcp1109290

189. Sadov S, Koskenniemi JJ, Virtanen HE, Perheentupa A, Petersen JH, Skakkebaek NE, et al. Testicular growth during puberty in boys with and without a history of congenital cryptorchidism. J Clin Endocrinol Metab. (2016) 101:2570-7. doi: 10.1210/jc.2015-3329

190. Tinggaard J, Mieritz MG, Sørensen K, Mouritsen A, Hagen CP, Aksglaede L, et al. The physiology and timing of male puberty. Curr Opin Endocrinol Diabetes Obes. (2012) 19:197-203. doi: 10.1097/MED.0b013e3283535614

191. Ankarberg-Lindgren C, Norjavaara E. Changes of diurnal rhythm and levels of total and free testosterone secretion from pre to late puberty in boys: testis size of $3 \mathrm{ml}$ is a transition stage to puberty. Eur J Endocrinol. (2004) 151:747-57. doi: 10.1530/eje.0.1510747

192. Wu F, Brown D, Butler G, Stirling H, Kelnar C. Early morning plasma testosterone is an accurate predictor of imminent pubertal development in prepubertal boys. Endocrinol Metab. (1993) 76:26-31. doi: 10.1210/jcem.76.1.8421096

193. Wu F, Butler G, Kelnar C, Huhtaniemi I, Veldhuis J. Ontogeny of pulsatile gonadotropin releasing hormone secretion from midchildhood, through puberty, to adulthood in the human male: a study using deconvolution analysis and an ultrasensitive immunofluorometric assay. J Clin Endocrinol Metab. (1996) 81:1798-805. doi: 10.1210/jcem.81.5.8626838

194. Andersson AM, Juul A, Petersen JH, Müller J, Groome NP, Skakkebæk NE. Serum inhibin B in healthy pubertal and adolescent boys: relation to age, stage of puberty, and follicle-stimulating hormone, luteinizing hormone, testosterone, and estradiol levels. J Clin Endocrinol Metab. (1997) 82:397681. doi: $10.1210 /$ jc. 82.12 .3976

195. Lewis K, Lee PA. Endocrinology of male puberty. Curr Opin Endocrinol Diabetes Obes. (2009) 16:5-9. doi: 10.1097/MED.0b013e32832029be

196. van Brakel J, Kranse R, de Muinck Keizer-Schrama SM, Hendriks AE, de Jong FH, Hack WW, et al. Fertility potential in a cohort of 65 men with previously acquired undescended testes. J Pediatr Surg. (2014) 49:599-605. doi: 10.1016/j.jpedsurg.2013.09.020

197. Taskinen S, Hovatta O, Wikström S. Sexual development in patients treated for cryptorchidism. Scand J Urol Nephrol. (1997) 31:361-4. doi: 10.3109/00365599709030620

198. Arendt LH, Ernst A, Lauridsen LLB, Brix N, Olsen J, Ramlau-Hansen CH. Timing of pubertal development in boys born with cryptorchidism and hypospadias: a nationwide cohort study. Asian J Androl. (2017) 19:512-4. doi: 10.4103/aja.aja_3_19

199. Matsumoto A, Bremner W. Testicular disorders. In: Melmed S, Polonsky KS, Reed Larsen P, Kronenberg HM, editors. Williams Textbook of Endocrinology. 13th ed. Elsevier (2016), p. 694-784.

200. Varela-Cives R, Méndez-Gallart R, Estevez-Martínez E, RodríguezBarca P, Bautista-Casasnovas A, Pombo-Arias M, et al. A cross-sectional study of cryptorchidism in children: testicular volume and hormonal function at 18 years of age. Int Braz J Urol. (2015) 41:57-66. doi: 10.1590/S1677-5538.IBJU.2015.01.09

201. Kollin C, Karpe B, Hesser U, Granholm T, Ritzén EM. Surgical treatment of unilaterally undescended testes: testicular growth after randomization to orchiopexy at age 9 months or 3 years. J Urol. (2007) 178(4 Pt 2):1589-93. doi: 10.1016/j.juro.2007.03.173

202. Kollin C, Granholm T, Nordenskjold A, Ritzen EM. Growth of spontaneously descended and surgically treated testes during early childhood. Pediatrics. (2013) 131:e1174-80. doi: 10.1542/peds.2012-2902

203. Vikraman J, Hutson JM, Li R, Thorup J. The undescended testis: clinical management and scientific advances. Semin Pediatr Surg. (2016) 25:241-8. doi: 10.1053/j.sempedsurg.2016.05.007

204. Cobellis G, Noviello C, Nino F, Romano M, Mariscoli F, Martino A, et al. Spermatogenesis and cryptorchidism. Front Endocrinol. (2014) 5:63. doi: 10.3389 /fendo. 2014.00063

205. Ivell R, Hartung S. The molecular basis of cryptorchidism. Mol Hum Reprod. (2003) 9:175-81. doi: 10.1093/molehr/gag025

206. Rusnack SL, Wu H-Y, Huff DS, Snyder HM, Zderic SA, Carr $\mathrm{MC}$, et al. The ascending testis and the testis undescended since birth share the same histopathology. J Urol. (2002) 168:2590-1. doi: 10.1016/S0022-5347(05)64223-1

207. Akre O, Pettersson A, Richiardi L. Risk of contralateral testicular cancer among men with unilaterally undescended testis: a meta analysis. Int $J$ Cancer. (2009) 124:687-9. doi: 10.1002/ijc.23936

208. Trsinar B, Muravec UR. Fertility potential after unilateral and bilateral orchidopexy for cryptorchidism. World J Urol. (2009) 27:513-9. doi: 10.1007/s00345-009-0406-0

209. Adomaitis R, Vincel B, Eidukaite A, Ostaneviciute E, Kirka R, Bilius V, et al. Consequences of bilateral cryptorchidism in adults. Andrologia. (2016) 48:1021-6. doi: 10.1111/and.12534

210. Lee PA, Coughlin MT. Leydig cell function after cryptorchidism: evidence of the beneficial result of early surgery. J Urol. (2002) 167:1824-7. doi: 10.1016/S0022-5347(05)65241-X

211. Sánchez García J, Sánchez Zalabardo J, Ferrández A, Gracia J, García C. Clinical, physical, sperm and hormonal data in 251 adults operated on for cryptorchidism in childhood. BJU Int. (2003) 85:1100-3. doi: 10.1046/j.1464-410x.2000.00662.x

212. Tasian GE, Hittelman AB, Kim GE, DiSandro MJ, Baskin LS. Age at orchiopexy and testis palpability predict germ and Leydig cell loss: clinical predictors of adverse histological features of cryptorchidism. J Urol. (2009) 182:704-9. doi: 10.1016/j.juro.2009.04.032

213. Allin BSR, Dumann E, Fawkner-Corbett D, Kwok C, Skerritt C, Paediatric Surgery Trainees Research Network. Systematic review and meta-analysis comparing outcomes following orchidopexy for cryptorchidism before or after 1 year of age. BJS Open. (2018) 2:1-12. doi: 10.1002/bjs5.36

214. Thorup J, Clasen-Linde E, Thorup SC, Cortes D. Pre- and postoperative status of gonadotropins (FSH and LH) and inhibin-B in relation to testicular histopathology at orchiopexy in infant boys with unilateral undescended testes. J Pediatr Urol. (2015) 11:25.e1-e5. doi: 10.1016/j.jpurol.2014.08.007

215. Kraft KH, Canning DA, Snyder HM, Kolon TF. Undescended testis histology correlation with Adult Hormone Levels and Semen Analysis. J Urol. (2012) 188:1429-35. doi: 10.1016/j.juro.2012.04.025

216. Lee PA, Coughlin MT, Bellinger MF. Paternity and hormone levels after unilateral cryptorchidism: association with pretreatment testicular location. J Urol. (2000) 164:1697-701. doi: 10.1016/S0022-5347(05)67087-5

217. Cortes D, Petersen BL, Thorup J. Testicular histology in cryptorchid boys aspects of fertility. J Pediatr Surg Spec. (2007) 1:32-5.

218. Kolon TF, Herndon CD, Baker LA, Baskin LS, Baxter CG, Cheng EY, et al. Evaluation and treatment of Cryptorchidism: AUA guideline. J Urol. (2014) 192:337-45. doi: 10.1016/j.juro.2014.05.005

219. Martin Ritzén E, Bergh A, Bjerknes R, Christiansen P, Cortes D, Haugen S, et al. Nordic consensus on treatment of undescended testes. Acta Paediatr. (2007) 96:638-43. doi: 10.1111/j.1651-2227.2006.00159.x

220. Taskinen S, Hovatta O, Wikstrom S. Early treatment of cryptorchidism, semen quality and testicular endocrinology. J Urol. (1996) 156:82-4. doi: 10.1016/S0022-5347(01)65946-9

221. Hadziselimovic F, Herzog B. The importance of both an early orchidopexy and germ cell maturation for fertility. Lancet. (2001) 358:1156-7. doi: 10.1016/S0140-6736(01)06274-2

222. Rajfer J, Handelsman DJ, Swerdloff RS, Hurwitz R, Kaplan H, Vandergast T, et al. Hormonal therapy of cryptorchidism. N Engl J Med. (1986) 314:466-70. doi: 10.1056/NEJM198602203140802 
223. Henna MR, Del Nero RG, Sampaio CZ, Atallah AN, Schettini ST, Castro AA, et al. Hormonal cryptorchidism therapy: systematic review with metanalysis of randomized clinical trials. Pediatr Surg Int. (2004) 20:357-9. doi: 10.1007/s00383-004-1198-3

224. Pyörälä S, Huttunen N, Uhari M. A review and meta-analysis of hormonal treatment of cryptorchidism. J Clin Endocrinol Metab. (1995) 80:2795-9. doi: $10.1210 /$ jcem.80.9.7673426

225. Penson D, Krishnaswami S, Jules A, McPheeters ML. Effectiveness of hormonal and surgical therapies for cryptorchidism: a systematic review. Pediatrics. (2013) 131:e1897-907. doi: 10.1542/peds.2013-0072

226. Li T, Gao L, Chen P, Bu S, Cao D, Yang L, et al. A systematic review and meta-analysis of comparative studies assessing the efficacy of luteinizing hormone-releasing hormone therapy for children with cryptorchidism. Int Urol Nephrol. (2016) 48:635-44. doi: 10.1007/s11255-016-1235-x

227. Wei Y, Wang Y, Tang X, Liu B, Shen L, Long C, et al. Efficacy and safety of human chorionic gonadotropin for treatment of cryptorchidism: a metaanalysis of randomised controlled trials. J Paediatr Child Health. (2018) 54:900-6. doi: 10.1111/jpc. 13920

228. Cortes D, Thorup J, Visfeldt J. Hormonal treatment may harm the germ cells in 1 to 3-year-old boys with cryptorchidism. J Urol. (2000) 163:1290-2. doi: 10.1016/S0022-5347(05)67763-4

229. Heiskanen P, Billig H, Toppari J, Kaleva M, Arsalo A, Rapola J, et al. Apoptotic cell death in the normal and cryptorchid human testis: the effect of human chorionic gonadotropin on testicular cell survival. Pediatr Res. (1996) 40:351-6. doi: 10.1203/00006450-199608000-00026

230. Dunkel L, Taskinen S, Hovatta O, Tilly JL, Wikström S. Germ cell apoptosis after treatment of cryptorchidism with human chorionic gonadotropin is associated with impaired reproductive function in the adult. J Clin Invest. (1997) 100:2341-6. doi: 10.1172/JCI119773

231. Chua ME, Mendoza JS, Gaston MJ V., Luna SL, Morales ML. Hormonal therapy using gonadotropin releasing hormone for improvement of fertility index among children with cryptorchidism: a metaanalysis and systematic review. J Pediatr Surg. (2014) 49:1659-67. doi: 10.1016/j.jpedsurg.2014.06.013

232. Hadziselimovic F. Cryptorchidism, its impact on male fertility. Eur Urol. (2002) 41:121-3. doi: 10.1016/S0302-2838(01)00040-9

233. Schwentner C, Oswald J, Kreczy A, Lunacek A, Bartsch G, Deibl M, et al. Neoadjuvant gonadotropin-releasing hormone therapy before surgery may improve the fertility index in undescended testes: a prospective randomized trial. J Urol. (2005) 173:974-7. doi: 10.1097/01.ju.0000153562.07287.77

234. Thorup J, Clasen-Linde E, Dong L, Hildorf S, Kristensen SG, Andersen CY, et al. Selecting infants with cryptorchidism and high risk of infertility for optional adjuvant hormonal therapy and cryopreservation of germ cells: experience from a pilot study. Front Endocrinol. (2018) 9:1-7. doi: 10.3389/fendo.2018.00299

235. Hadziselimovic F, Herzog B. Treatment with a luteinizing hormonereleasing hormone analogue after successful orchiopexy markedly improves the change of fertility later in life. J Urol. (1997) $158(3 \mathrm{Pt} 2): 1193-5$. doi: 10.1016/S0022-5347(01)64422-7
236. Trabado S, Lamothe S, Maione L, Bouvattier C, Sarfati J, Brailly-Tabard S, et al. Congenital hypogonadotropic hypogonadism and Kallmann syndrome as models for studying hormonal regulation of human testicular endocrine functions. Ann Endocrinol. (2014) 75:79-87. doi: 10.1016/j.ando.2014.04.011

237. Young J, Xu C, Papadakis GE, Acierno JS, Maione L, Hietamäki J, et al. Clinical management of congenital hypogonadotropic hypogonadism. Endocr Rev. (2019) 40:669-710. doi: 10.1210/er.2018-00116

238. Quigley CA. Editorial: the postnatal gonadotropin and sex steroid surge insights from the androgen insensitivity syndrome. J Clin Endocrinol Metab. (2002) 87:24-8. doi: 10.1210/jc.87.1.24

239. Raivio T, Wikström AM, Dunkel L. Treatment of gonadotropin-deficient boys with recombinant human FSH: long-term observation and outcome. Eur J Endocrinol. (2007) 156:105-11. doi: 10.1530/eje.1.02315

240. Bouvattier C, Maione L, Bouligand J, Dodé C, Guiochon-Mantel A, Young J. Neonatal gonadotropin therapy in male congenital hypogonadotropic hypogonadism. Nat Rev Endocrinol. (2012) 8:172-82. doi: $10.1038 /$ nrendo.2011.164

241. Kohva E, Huopio H, Hero M, Miettinen PJ, Vaaralahti K, Sidoroff V, et al. Recombinant human FSH treatment outcomes in five boys with severe congenital hypogonadotropic hypogonadism. J Endocr Soc. (2018) 2:134556. doi: 10.1210/js.2018-00225

242. Kohva E, Huopio H, Hietamäki J, Hero M, Miettinen PJ, Raivio T. Treatment of gonadotropin deficiency during the first year of life: longterm observation and outcome in five boys. Hum Reprod. (2019) 34:863-71. doi: 10.1093/humrep/dez040

243. Raivio T, Toppari J, Perheentupa A, McNeilly AS, Dunkel L. Treatment of prepubertal gonadotrophin-deficient boys with recombinant human follicle-stimulating hormone. Lancet. (1997) 350:263-4. doi: 10.1016/S0140-6736(05)62227-1

244. Papadimitriou DT, Chrysis D, Nyktari G, Zoupanos G, Liakou E, Papadimitriou A, et al. Replacement of male minipuberty. J Endocr Soc. (2019) 3:1275-82. doi: 10.1210/js.201900083

245. Lambert A, Bougneres P. Growth and descent of the testes in infants with hypogonadotropic hypogonadism receiving subcutaneous gonadotropin infusion. Int J Pediatr Endocrinol. (2016) 2016:1-6. doi: 10.1186/s13633-016-0031-9

Conflict of Interest: The authors declare that the research was conducted in the absence of any commercial or financial relationships that could be construed as a potential conflict of interest.

Copyright (C) 2020 Rodprasert, Virtanen, Mäkelä and Toppari. This is an open-access article distributed under the terms of the Creative Commons Attribution License (CC $B Y)$. The use, distribution or reproduction in other forums is permitted, provided the original author(s) and the copyright owner(s) are credited and that the original publication in this journal is cited, in accordance with accepted academic practice. No use, distribution or reproduction is permitted which does not comply with these terms. 